\section{Nauplius}

The Journal of The

Brazilian Crustacean Society

e-ISSN 2358-2936

www.scielo.br/nau www.crustacea.org.br
This article is part of the special series offered by the Brazilian Crustacean Society in honor to Ludwig Buckup in recognition of his dedication and contributions to the development of Carcinology

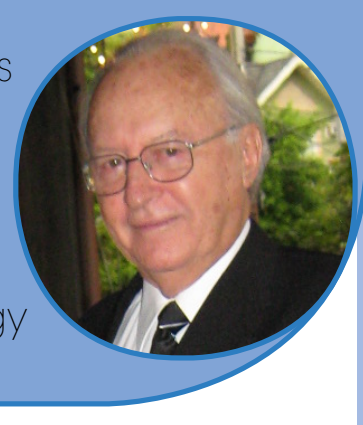

Original Article

\title{
Freshwater crabs (Decapoda: Brachyura: Pseudothelphusidae, Trichodactylidae) from the state of Roraima, Brazil: species composition, distribution and new records
}

Francinéia Zanetti ${ }^{1}$ (D) orcid.org/0000-0002-2118-6153

Patrícia Macedo de Castro ${ }^{2,3}$ (D) orcid.org/0000-0003-2426-8936

Célio Magalhães ${ }^{4}$ iD orcid.org/0000-0003-4858-2575

1 Instituto Nacional de Pesquisas da Amazônia, Programa de Pós-Graduação em Biologia de Água Doce e Pesca Interior. Av. André Araújo, 2936 - Petrópolis. 69067-375 Manaus, Amazonas, Brazil

FZ E-mail: frannzanetti@gmail.com

2 Universidade Estadual de Roraima, Pró-Reitoria de Pesquisa e Pós-Graduação. Rua Sete de Setembro, 231 - Canarinho. 69306-530 Boa Vista, Roraima, Brazil. PMC E-mail: patriciacastro@uerr.edu.br

3 Museu Integrado de Roraima/IACTI-RR. Av. Brigadeiro Eduardo Gomes, 2868 Pq. Anauá. 69305-010 Boa Vista, Roraima, Brazil.

4 Instituto Nacional de Pesquisas da Amazônia, Coordenação de Biodiversidade. Av. André Araújo, 2936 - Petrópolis. 69067-375 Manaus, Amazonas, Brazil CM E-mail: celiomag@inpa.gov.br

ZOOBANK http://zoobank.org/urn:1sid:zoobank.org:pub:3A322C24-0665-450BA170-75F8956DFEA3

CORRESPONDING AUTHOR Célio Magalhães celiomag@inpa.gov.br SUBMITTED 02 November 2017 ACCEPTED 29 March 2018 PUBLISHED 04 June 2018

Guest Editors

Alessandra Angélica de Pádua Bueno and Sandro Santos

DOI 10.1590/2358-2936e2018011

\section{(cc) BY}

All content of the journal, except where identified, is licensed under a Creative Commons attribution-type BY.

Nauplius, 26: e2018011

\section{Abstract}

The species composition and distribution of the pseudothelphusid and trichodactylid freshwater crabs from the state of Roraima, Brazil, are updated based mainly on documented records deposited in the collections of the Instituto Nacional de Pesquisas da Amazônia (Manaus) and the Museu Integrado de Roraima (Boa Vista). This paper provides records for the occurrence of ten species (six Pseudothelphusidae, four Trichodactylidae). Three species are recorded from Roraima for the first time: the pseudothelphusids Fredius beccarii (Coifmann, 1939) and Fredius fittkaui (Bott, 1967), and the trichodactylid Moreirocarcinus laevifrons (Moreira, 
1901). The records of F. beccarii also represent the first documented occurrence of the species in Brazil. All species in the state are presented in maps that document their geographic distribution. Comments are made on the diversity of the Branco River crab fauna in comparision with diversity in other sub-basins of the Amazon River.

\section{KEY WORDS}

Amazon region, geographic distribution, Guyana Shield, Neotropical region, new record.

\section{INTRODUCTION}

The Brazilian state of Roraima is situated in the northern limits of the Amazon Basin. Despite its small territory $\left(225,116 \mathrm{~km}^{2}\right)$, Roraima is ecologically diversified due to marked differences in climate, vegetation, geomorphology, landscape and river drainages (Barbosa et al., 1997; Ferreira et al., 2007). Magalhães and Pereira (2007) listed ten pseudothelphusid and eight trichodactylid species of crabs for the whole Negro River basin, which, covering $700.000 \mathrm{~km}^{2}$, comprises the third largest tributary area of the Amazon drainage, and $10.1 \%$ of the whole Amazon basin (Goulding et al., 2003). The Branco River, which is the largest sub-basin in the Negro River, drains most of Roraima's territory and yet its freshwater crab fauna is not well known. To date, seven species have been recorded from the state, based on few, sporadic samples. Magalhães (1986) documented the ocurrence of the pseudothelphusid, Kingsleya latifrons (Randall, 1840), and Magalhães and Türkay (1996b; 2008a) recorded two species of trichodactylids: Sylviocarcinus pictus (H. Milne Edwards, 1853) and Poppiana dentata (Randall, 1840), respectively. These same records were used by Magalhães $(1998 ; 2003$ ) for contributions to a catalogue and the manual for the identification of Brazilian crustaceans, respectively. More recently, Castro and Silva (2013) extended the distribution of the trichodactylid crab, Valdivia serrata White, 1847, to the state of Roraima. Magalhães et al. (2014) listed Fredius estevisi Rodriguez, 1966, Fredius platyacanthus Rodríguez and Pereira, 1992, and Fredius stenolobus Rodríguez and Suárez, 1994 as species collected in Roraima among species used for comparison in a molecular study. Magalhães and Pereira's (2007) inventory of the Negro River basin included the published records (Magalhães, 1986; Magalhães and Türkay, 1996) and some unpublished records at the time for F. estevisi, F. platyacanthus, F. stenolobus, and P. dentata (CM, pers. obs.) in their compilation.
Carcinological surveys made during the last decade in several areas throughout the state revealed that its freshwater crab fauna is more diverse and widespread than currently known. The purpose of this paper is to document the occurrence and distribution of several species of both pseudothelphusid and trichodactylid crabs in Roraima, and to extend the range of distribution of some of these species into the Amazon River basin in Brazil.

\section{Material and Methods}

\section{Study area}

Roraima is the northernmost of the Brazilian states, located between the geographic coordinates $05^{\circ} 16^{\prime} \mathrm{N}$ and $01^{\circ} 25^{\prime} \mathrm{S}$, and $058^{\circ} 55^{\prime} \mathrm{W}$ and $64^{\circ} 48^{\prime} \mathrm{W}$, and bordered by Venezuela in the west and north, and Guyana in the east (Ferreira et al., 2007). The hydrographic system is dominated by the Branco River, whose watershed covers $187,540 \mathrm{~km}^{2}$, comprising $83 \%$ of the state territory (Carvalho, 2015). The river is formed by the confluence of the Uraricoera River and Tacutu River and flows northeast-southwest for $566 \mathrm{~km}$. Other main rivers are the Xeruini and Jauaperi Rivers (tributaries of the Negro River), and Jatapu River (tributary of the Amazon River), all located in the south and southeastern portion of the state (Santos et al., 1985; Ferreira et al., 2007; Carvalho, 2015). Roraima is situated within the boundaries of the Guyana Shield region as defined in Huber (1995) and in the Remarks and Discussion sections we use the hydrologic limits of the region as defined in Lujan and Armbruster (2011: 212, fig. 13.1).

\section{Data collection}

The specimens were obtained either from field surveys, conducted in several localities throughout the state between April 2014 and April 2015, or from material deposited in the collections of the Instituto 
Nacional de Pesquisas da Amazônia, Manaus (INPA), Instituto Venezolano de Investigaciones Científicas, Caracas (IVIC), Museu Integrado de Roraima, Boa Vista (MIRR), Museu Nacional, Universidade Federal do Rio de Janeiro, Rio de Janeiro (MNRJ), Museu de Zoologia, Universidade de São Paulo, São Paulo (MZUSP), and Universidad Nacional Autónoma de México, Colección Nacional de Crustáceos, Mexico City (CNCR). Fresh material was fixed in 90\% ethanol, preserved in $70 \%$ ethanol, and deposited in the INPA collection. All sampling was done according to the permit issued by IBAMA (SISBIO \# 44857-1).

\section{Taxonomic and distributional analysis}

The taxonomic identification was carried out using the keys, descriptions and illustrations available in Magalhães $(1986 ; 2003)$ and other pertinent publications when necessary (Magalhães and Türkay, 1996a; 1996b; 1996c; 2008; Magalhães and Rodríguez, 2002; Magalhães, 2010), as well as by comparison with identified material in the INPA collection. Suprageneric classification follows Ahyong et al. (2011), and the taxa are organized alphabetically. The distribution maps were generated using the QGIS software, v. 2.14.16 (http://www.qgis.org/pt_BR/site/), following the instructions presented in the second part of the tutorial by Calegari et al. (2016). The geographic coordinates of each record were obtained either from a GPS apparatus during sampling or from data on the labels of the collection lots. When coorditantes were unavaliable, the localities were georeferenced using Google Earth ${ }^{\circ}$ software and online gazetteers (GeoNames: http:// www.geonames.org/) and these are noted between parentheses; those coordinates informed between brackets represent the municipality seat, since the locality could not be determined with reasonable accuracy. To generate the maps, the coordinates were all converted to decimal degrees using WGS84 datum (the same datum used in the GPS receiver employed during sampling), according to the calculator provided by the Instituto Nacional de Pesquisas Espaciais (http:// www.dpi.inpe.br/calcula/).

\section{Conventions}

Measurements of the crab carapace are in millimeters when they are available; carapace width was measured across the carapace at its widest point, and carapace length was measured along the midline, from the frontal to the posterior margin. Both measurements follow the number and sex of the specimens examined and are given between parenthesis as (carapace width:carapace length); in lots with more than three species, only the measurements of the smallest and the largest specimens are informed. G1 refers to the first male gonopod. Abbreviations used are: "ad." for adult(s); "elev." for elevation; "immat." for immature specimen; "juv." for juvenile(s); "mun." for municipality, "ov." for ovigerous; "trib." for tributary. In 'Material examined' the names of geographic elements were kept as written in Portuguese on the original labels and mean: cachoeira = falls; fazenda $=$ farm; igarapé $=$ small river, stream; lago = lake; PARNA = National Park; praia = beach; PIN = Posto Indígena (Indigenous Health Post); rio = river; serra $=$ mountain range; sítio $=$ small farm; vicinal $=$ side road; vila = village. The names of some landforms, particularly those in the Brazilian territory, were written according to the spelling in Portuguese.

\section{Results}

The total number of freshwater crab species known in the state of Roraima increased to ten: six Pseudothelphusidae and four Trichodactylidae. Three species are recorded from Roraima for the first time: the pseudothelphusids Fredius beccarii (Coifmann, 1939) and Fredius fittkaui (Bott, 1967), and the trichodactylid Moreirocarcinus laevifrons (Moreira, 1901). The records of $F$. beccarii also represent the first occurrence of the species in Brazil.

\section{Pseudothelphusidae Ortmann, 1893}

\section{Genus Fredius Pretzmann, 1967}

\section{Fredius beccarii (Coifmann, 1939)}

(Figs. 1A, 3)

Material examined. BRAZIL, Roraima: 1 male (40.2:26.4), MIRR 95, mun. Amajarí, Tepequém, RR 203 road, igarapé Pau Baru, 0341'N 06141'W, 24.ii.2011, F. Zanetti, A.A. Otaviano, A.S. Sales and D. Teixieira; 1 male (35.7:23.8) 1 female (33.2:22.4), INPA 1895, mun. Amajarí, vila Bom Jesus, vicinal II, Trairão, igarapé Coimbra, 033ํN 06149’W, 24.ii.2011, F. Zanetti, A.A. Otaviano, A.S. Sales and 

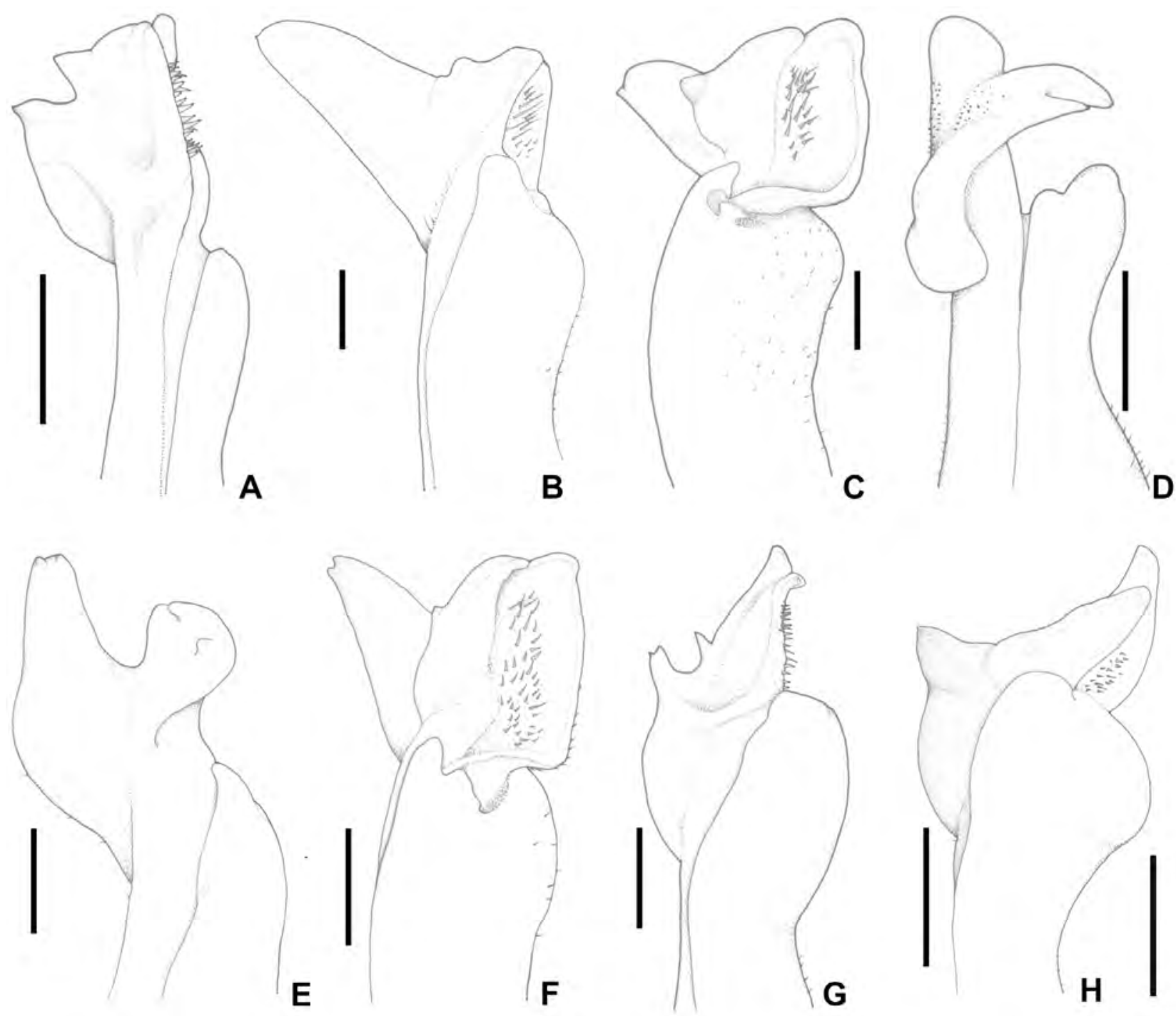

Figure 1. Male first gonopod, left side, distal part, of the pseudothelphusid crabs from Roraima. A, Fredius beccarii (Coifmann, 1939), mesio-caudal view, INPA 1895; B, Fredius estevisi (Rodríguez, 1966), mesio-caudal view, INPA 839; C, F. estevisi, latero-caudal view, INPA 839; D, Fredius fittkaui (Bott, 1967), mesial view, INPA 1338; E, Fredius platyacanthus Rodriguez and Pereira, 1992, mesial view, INPA 840; F, F. platyacanthus, lateral view, INPA 840; G, Fredius stenolobus Rodríguez and Suárez, 1994, mesio-caudal view, INPA 1252; H, Kingsleya latifrons (Randall, 1840), mesio-caudal view, INPA 1248.

D. Teixeira, F.C. Zanetti, A.A. Otaviano, A.S. Sales and Neiva; 3 males (29.2:19.9-43.5:28.9), 7 females (27.7:19.4-88.1:57.4), INPA 2435, mun. Amajarí, vila Bom Jesus, vicinal II, Trairão, igarapé do Coimbra, 033'ㅅ $061^{\circ} 49^{\prime} \mathrm{W}, 18 . i v .2015$, F. Zanetti and M.A.L. Santos; 2 males (21.2:14.9; 32.9:22.5) 1 young, MIRR 97, mun. Amajarí, vila Bom Jesus, vicinal II, Trairão, igarapé Coimbra, 0337’N 06149’W, 31.x.2009, F. Zanetti, P.M. Castro and D.A. Lima.
Distribution. Venezuela, Guyana, and Brazil [new record] (Roraima) (Rodriguez, 1982; this study).

Remarks. The G1s of our specimens (Fig. 1A) are morphological very similar to that of a specimen from the Rupununi River, in Guyana, figured by Rodriguez (1982: 135, fig. 129).

Until now, the species was known from eastern Venezuela and Guyana in the Essequibo River 

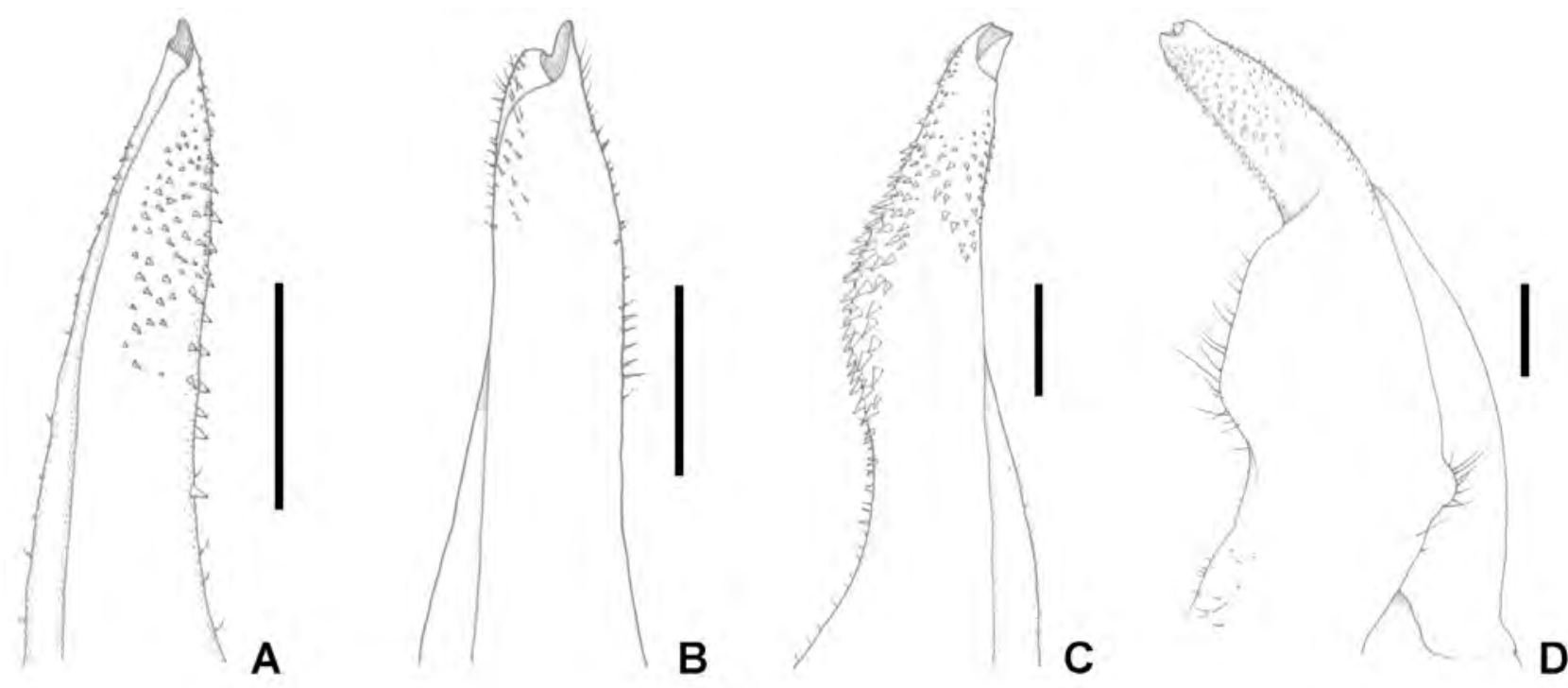

Figure 2. Male first gonopod, right side, of the trichodactylid crabs from Roraima. A, Moreirocarcinus laevifrons (Moreira, 1901), distal part, mesial view, INPA 1493; B. Poppiana dentata (Randall, 1840), distal part, mesial view, INPA 1896; C, Sylviocarcinus pictus (H. Milne Edwards, 1853), distal part, mesial view, INPA 1900; D, Valdivia serrata White, 1847, whole limb, mesio-caudal view, INPA 1505.

and Demerara River basins (Rodriguez, 1982). Its occurrence in the Uraricoera River basin indicates that the species can be found in both the northern and southern slopes of the Guyana Shield (Fig. 3).

\section{Fredius estevisi (Rodriguez, 1966)}

(Figs. 1B, C, 3)

Previous records. Magalhães and Pereira (2007: 124, in table 4 - listed under Negro River basin); Magalhães et al. (2014: 104, in table, 105).

Material examined. BRAZIL, Roraima: 3 males ( 2 immat.), 5 females (4 juv.), 4 youngs, INPA 2436, mun. Pacaraima, headwaters of rio Miang, 04 $29^{\prime} \mathrm{N}$ 061ํㄱ'W, 13.vi.2014. F. Zanetti, M.A.L. Santos, Farias, R.E.S., S.C. Emidio and F.R. Silva; 5 males, 8 females, INPA 2434, mun. Pacaraima, headwaters of rio Miang, $04^{\circ} 29^{\prime} \mathrm{N} 061^{\circ} 07^{\prime} \mathrm{W}, 24 . i .2015$. F. Zanetti, S.C. Emidio and T.E. Souza; 1 male (78.2:50.1) 2 females (64.2:40.1; 79.9:51.6), INPA 839, Yanomami Indigenous Reserve, igarapé Inajá, trib. of rio Parima, rio Uraricoera basin, PIN Parafuri, 0317'59”N 06400’30”W, 22.iv.1994, leg. L.S. Aquino and U.C. Barbosa.
Distribution. Venezuela and Brazil (Roraima) (Rodriguez and Pereira, 1992; Magalhães et al., 2014).

Remarks. Rodriguez and Pereira (1992) described a new subspecies, F. estevisi siapensis Rodríguez and Pereira, 1992, and distinguished it from the nominal subspecies by the mesial lobe of the G1, presenting "the proximal margin concave and the distal margin regularly arched", giving it a thumb-like appearance, whereas the nominal subspecies has a mesial lobe with proximal and distal margins more or less straight, showing a conical shape. The specimens from Roraima have a $\mathrm{G} 1$ with mesial lobe bearing a conical appearance (Fig. 1B, C) and are therefore assigned to the nominal species. Besides, the localities of the Roraima specimens (particularly those of the Miang River) (Fig. 3) are not geographically distant from the localities in the upper Caroni River presented by Rodriguez and Pereira (1992). According to these authors, the nominal form is distributed in the southeastern portion of the state of Bolívar, in the "Gran Sabana" region, mainly in tributaries of the upper Caroni River coming from the slopes of Mount Roraima and draining to the Orinoco River Basin, while F. estevisi siapensis occurs in the Siapa and Cunucunuma Rivers, in the Venezuelan state of Amazonas. 


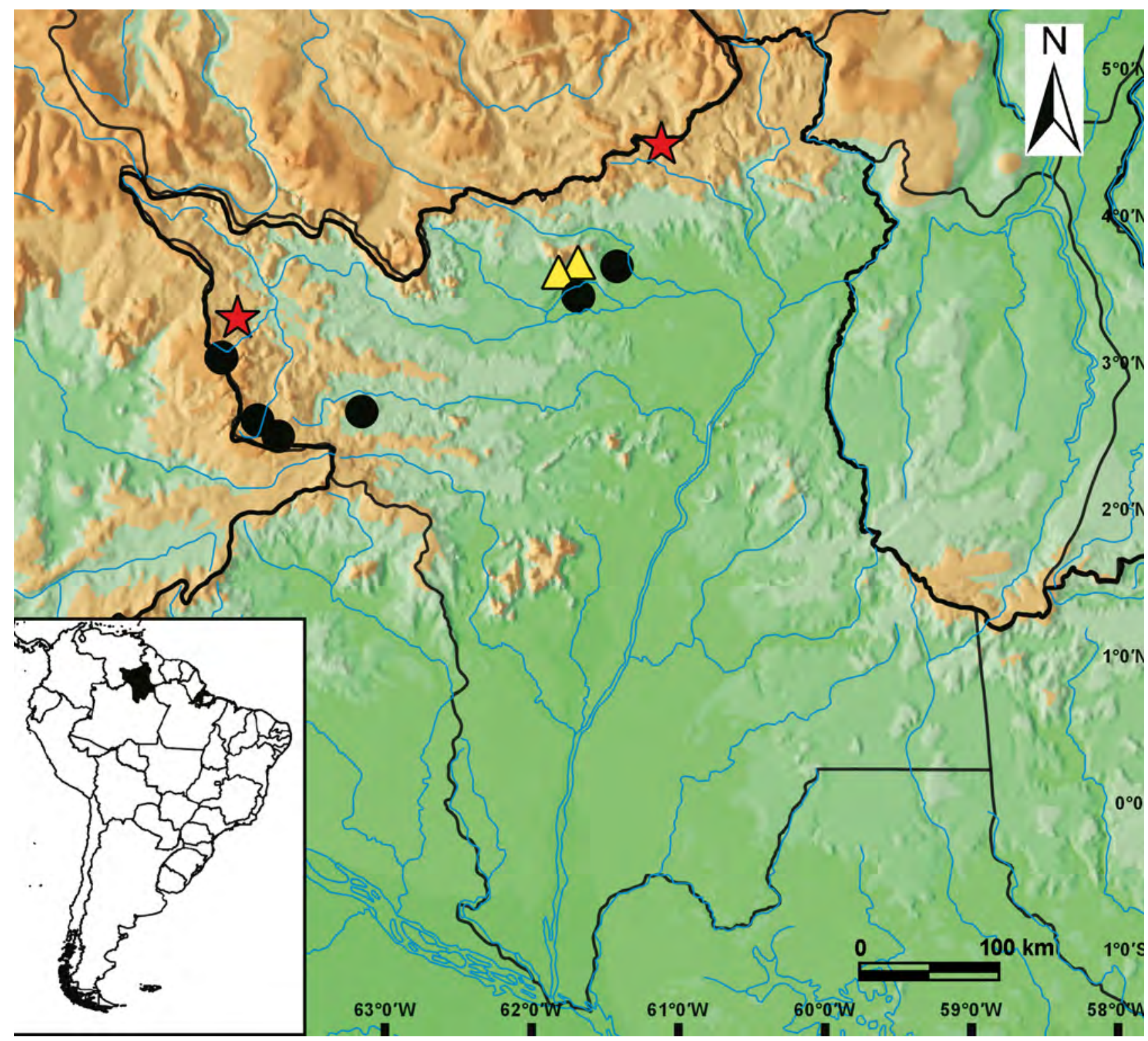

Figure 3. Distribution of the pseudothelphusid species, Fredius beccarii (Coifmann, 1939) (triangle), F. estevisi (Rodríguez, 1966) (star), and F. platyacanthus Rodriguez and Pereira, 1992 (circle), in the state of Roraima, Brazil.

Fredius fittkaui (Bott, 1967) (Figs. 1D, 4)

Distribution. Venezuela, Guyana, Brazil (Amazonas, Roraima [new record]) (Magalhães and Rodríguez, 2002; this study).

Material examined. BRAZIL, Roraima: 1 male (69.7:45.6), 1 female (64.0:41.5), INPA 2440, mun. Uiramutã [0435'59”N 06009'29”W], rio Cambarú, Maturucá indigenous village, 02.iii.2015, S. Silva; 4 immat. males (22.9:14.6-27.6:17.4), INPA 1338, Yanomami Indigenous Reserve, Rio Uxua-ú, PIN
Homoxi, 02²9'51”N 06343’47”W, 15.xi.2003, V. Py-Daniel and U.C. Barbosa.

Remarks. The G1s of the Roraima specimens (Fig. 1D) have all the morphological features as described for the G1 of the upper Negro River specimens by Magalhães and Rodríguez (2002): the well-developed, curved cephalic spine with a rounded tip; and an auxiliary lobe situated laterally and shorter than the cephalic lobe.

Fredius fittkaui has a disjunct distribution, occurring in the southwestern limits of the Guyana Shield in 


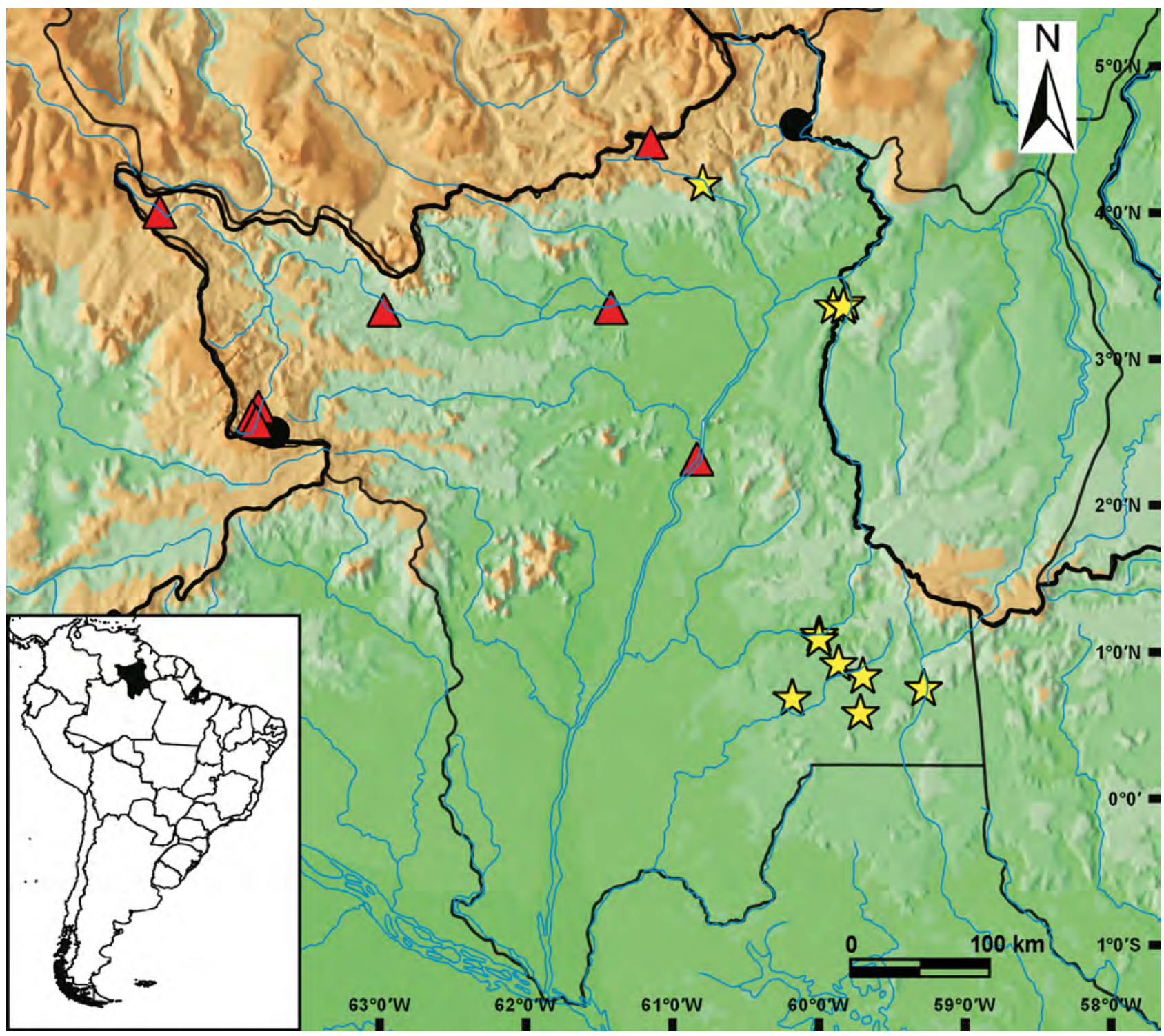

Figure 4. Distribution of the pseudothelphusid species, Fredius fittkaui (Bott, 1967) (circle), F. stenolobus Rodríguez and Suárez, 1994 (triangle), and Kingsleya latifrons (Randall, 1840) (star), in the state of Roraima, Brazil.

Brazil and Venezuela (with several records in northern tributaties of the upper Negro River), and in Guyana (Magalhães and Rodríguez, 2002). Unfortunately, the sole record available from Guyana lacks indication of a precise locality (Magalhães and Rodríguez, 2002). The present two records in the state of Roraima (Fig. 4) indicate that the species may have a continuous distribution along the tributaries of the Negro River and Branco River that drain the southern slopes of the Guyana Shield, probably reaching Guyana through the lowland areas along the Tacutu and upper Rupununi Rivers (see also Magalhães and Rodríguez, 2002: 687, fig. 4).

\section{Fredius platyacanthus Rodriguez and Pereira, 1992}

(Figs. 1E, F, 3)

Previous records. Magalhães and Pereira (2007: 124, tab. 4 - listed under Negro River basin); Magalhães et al. (2014: 104, in table, 105).

Distribution. Venezuela, Brazil (Amazonas, Roraima) (Rodriguez and Pereira, 1992; Magalhães et al., 2014; this study).

Material examined. BRAZIL, Roraima: 1 male (51.8:31.7), MIRR 43, mun. Amajarí [03³9’20”N $\left.061^{\circ} 25^{\prime} 16^{\prime \prime} \mathrm{W}\right]$, serra Tepequém, igarapé da Base, 


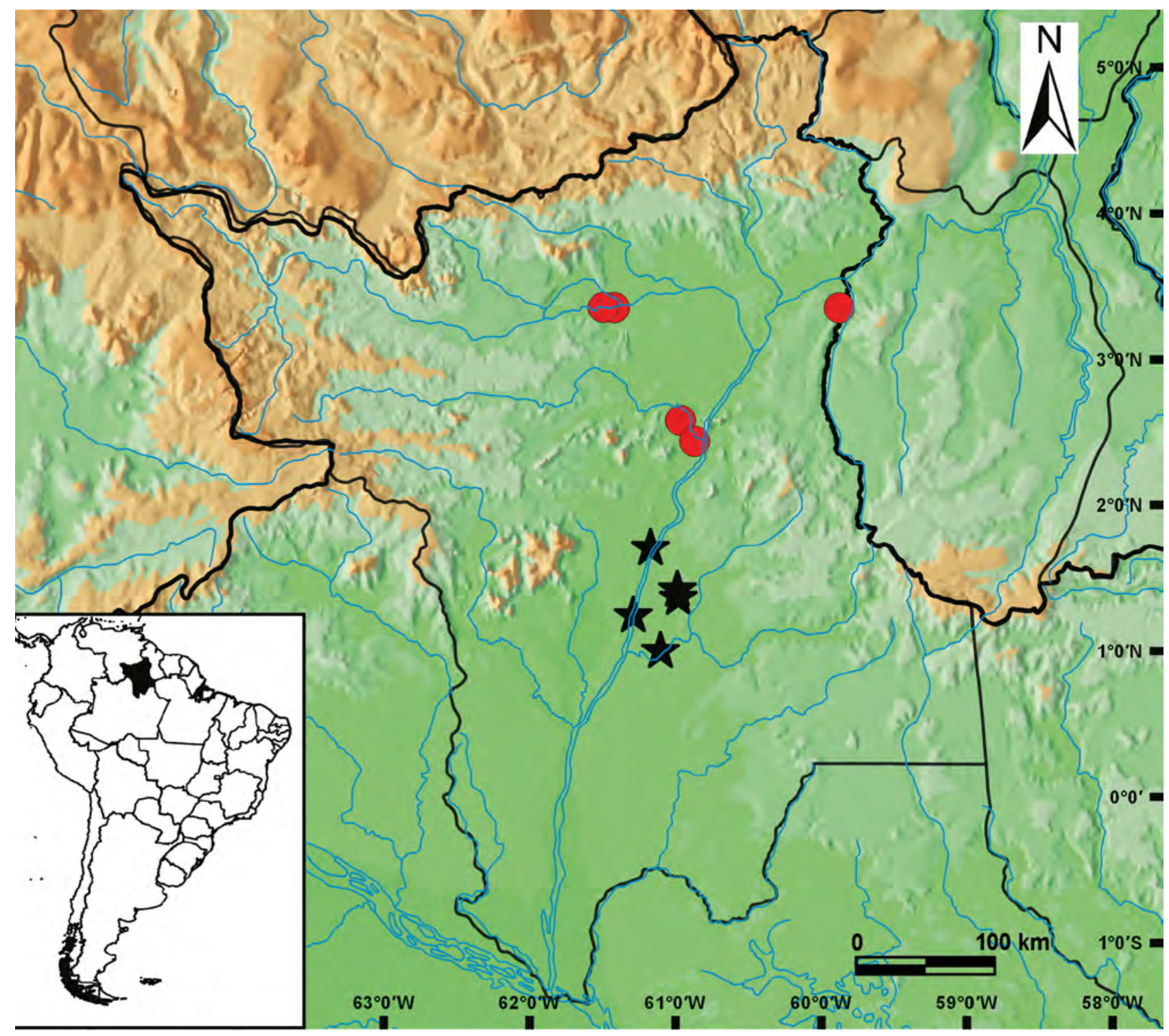

Figure 5. Distribution of the trichodactylid species, Moreirocarcinus laevifrons (Moreira, 1901) (star) and Poppiana dentata (Randall, 1840) (circle), in the state of Roraima, Brazil.

01.v.2009, L.F.R. Guterres et al.; 1 male (39.6:24.8), MIRR 96, mun. Amajarí [0339'20”N 061²5’16”W], serra Tepequém, igarapé da Base, 24.ii.2011, leg. F. Zanetti, A.A. Otaviano, A.S. Sales and D. Teixeira; 1 male (34.7:21.5), 1 female (47.0:29.0), MIRR 76, mun. Amajarí [033'ㅇ”N 061²5’16”W], igarapé Meio, 07.iv.2010, leg. R. Serafim and J.G.L. Neto; 1 male, MIRR 31, mun. Amajari, serra Tepequém, SESC Ecological Station, $03^{\circ} 27^{\prime} \mathrm{N} 061^{\circ} 41^{\prime} \mathrm{W}$, 25.viii.2008, L.F.R. Guterres, G.R.S. Abreu and I.M.M.C. Oliveira; 1 male (36.6:23.1), MIRR 42, mun. Amajarí, serra Tepequém, SESC Ecological Station, 03²7’ N $061^{\circ} 41^{\prime}$ W, 01.v.2009, leg. L.F.R. Guterres, P.M. Castro, F.C. Zanetti and J. Tavares; 1 ad. male (45.9:28.2),
4 immat. males, 1 female (24.1:15.2), MIRR 66, mun. Amajarí, serra Tepequém, SESC Ecological Station, 03²7'N 061 $41^{\circ}$ 'W, 30.x.2009, R. Denner and P.M. Castro; 2 males, MIRR 37, mun. Alto Alegre, Yanomami Indigenous Reserve, comunidade Koreaup, Surucucu, igarapé Inajá, 0302’ N 06407’W, 8.iv.2009, A.C.R. Vieira; 1 male (99.4:62.1), 2 females (95.6:61.5; 102.1:63.4), INPA 841, Yanomami Indigenous Reserve, upper rio Mucajaí basin, Community Paapiú, unnamed stream, 02³9'61”N 06309’31”W, 28.iv.1994, L.S. Aquino and U.C. Barbosa; 1 male (97.4:60.1, damaged), INPA 842; 1 male, 1 female, IVIC 1097; 1 male (78.2:48.3), MZUSP 13901; 1 male, MZUSP 13902, mun. Alto Alegre, Yanomami Indigenous Reserve, rio 


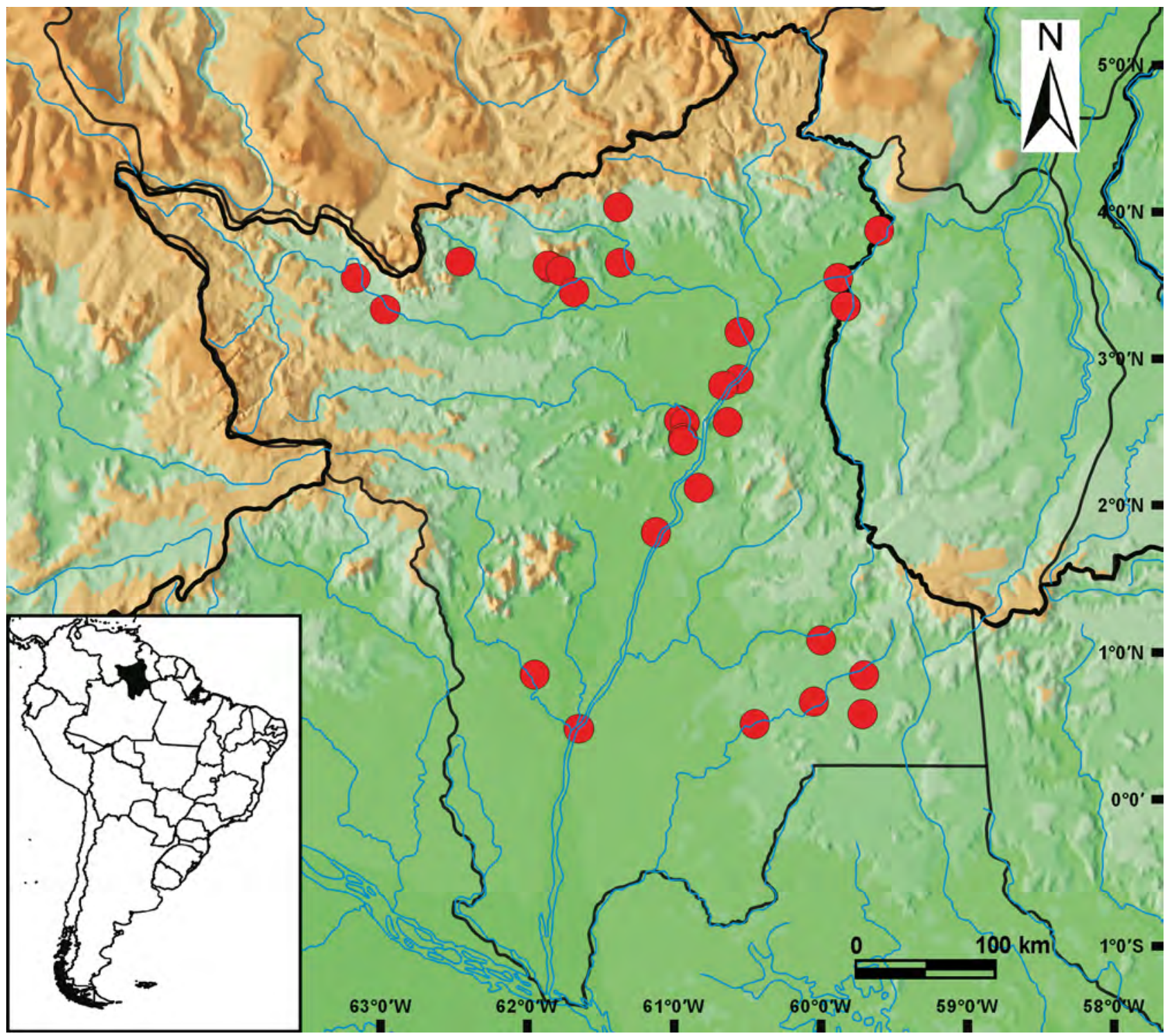

Figure 6. Distribution of the trichodactylid species, Sylviocarcinus pictus (H. Milne Edwards, 1853), in the state of Roraima, Brazil.

Parima basin (trib. of rio Uraricoera), rio Kanaakiú, PIN Xitei/Xidea, 02³6’29”N 06352'18”'W, 780 m elev., 03.vii.1995, V. Py-Daniel et al.; 1 male (54.1:33.1), INPA 840, mun. Alto Alegre, Yanomami Indigenous Reserve, rio Parima basin (trib. of rio Uraricoera), igarapé das Irmãs, cachoeira Grande, PIN Xitei/Xidea, 02 36’24”N $063^{\circ} 52^{\prime} 17^{\prime \prime}$ W, 750 m elev., 24.vi.1997, V. Py-Daniel et al.; 1 male (32.1:21.4), INPA 1337; 1 male (69.8:44.3), 2 females (92.1:57.6; 100.7:63.3), INPA 1329, mun. Alto Alegre, rio Uxua-ú, PIN Homoxi, 02 29'51”N 06343’47”W, 15.xi.2003, U. Barbosa.

Remarks. The G1s of the specimens studied herein (Fig. 1E, F) have the mesial process wide, with proximal margin distinctly convex in mesio-caudal view, and ending in a bifid tip; cephalic lobe auricular in latero-cephalic view, auxiliary lobe slightly shorter than cephalic one, with caudal border bearing small cephalic spine; field of apical spine well developed, wide, longitudinally situated along the latero-cephalic side. These features highly resemble those of the G1 of the holotype of F. platyacanthus that was figured by Rodriguez and Pereira (1992: 305, fig. 3), but some variations can be noticed: the cephalic lobe is a little shorter than the mesial process in the Roraima specimens (even considering the angle from which the illustration was made), and the cephalic spine is a bit smaller than that of the holotype.

Fredius platyacanthus was only known from the male holotype collected in the Icabaru River, a left bank 


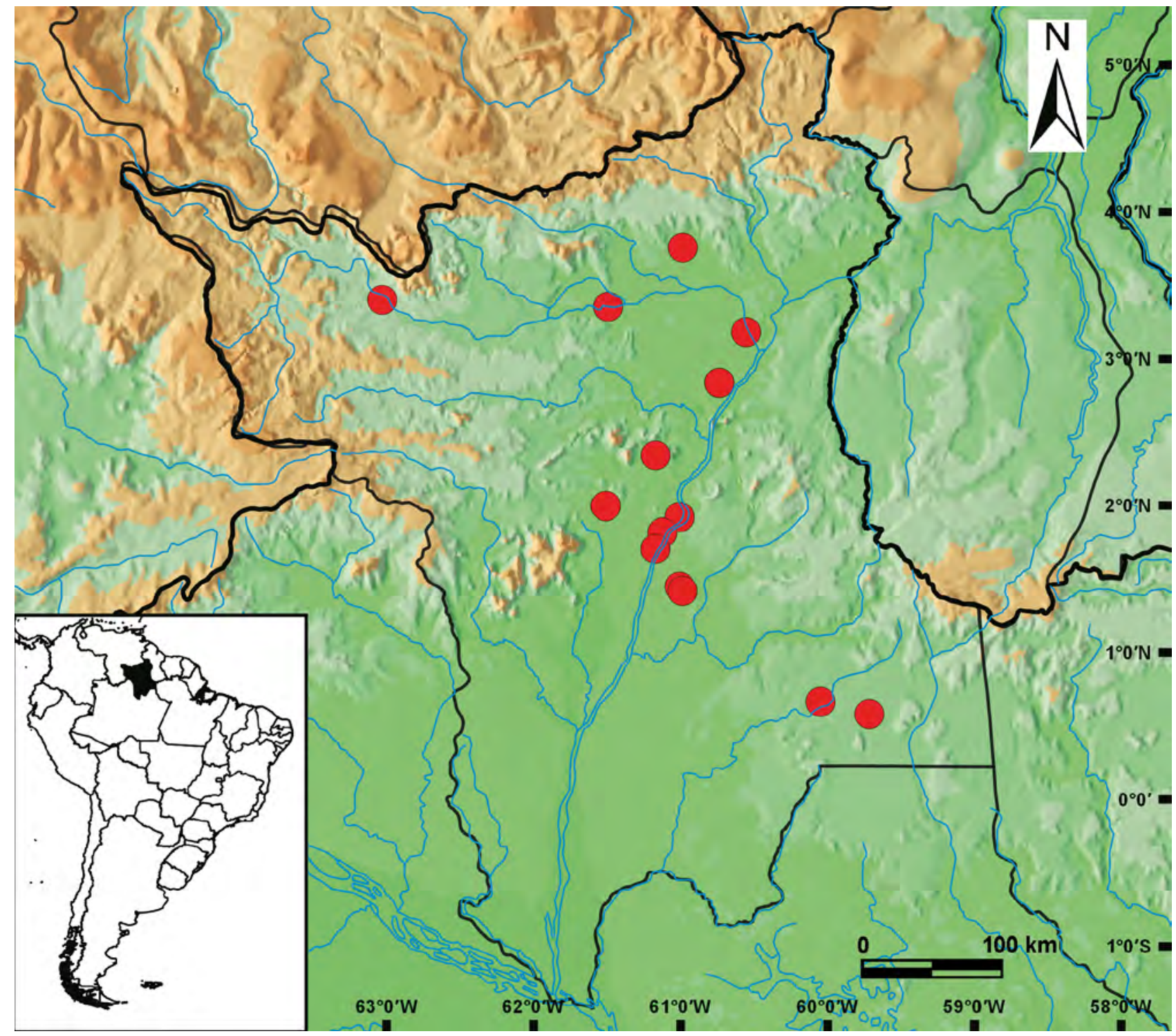

Figure 7. Distribution of the trichodactylid species, Valdivia serrata White 1847, in the state of Roraima, Brazil.

tributary of the upper Caroni River, in the Orinocoan slopes of the Serra Pacaraima. The several records presented above indicate that the species is more widely distributed on the Amazonian slopes of the Guyana Shield. In addition to the records the from the upper and middle course of the Uraricoera River (Fig. 3), Magalhães et al. (2006) recorded the species from the Yanomami village of Balawa-ú, in the state of Amazonas, Brazil, in the headwaters of the Demini River, a left tributary of the Negro River (the authors erroneously noted it as Fredius reflexifrons (Ortmann, 1897) in tab. 1).

At the moment, we prefer to consider our material as co-specific with the F. platyacanthus' type, since a more precise assessment of the variability of these
G1's features is not possible without examining a more abundant series of specimens from the upper Caroni River area.

\section{Fredius stenolobus Rodríguez and Suárez, 1994 (Figs. 1G, 4)}

Previous records. Magalhães and Pereira (2007: 124, tab. 4 - listed under Negro River basin); Magalhães et al. (2014: 104, in table, 107).

Material examined. BRAZIL, Roraima: 2 males, 2 females, MIRR 29, mun. Pacaraima [04 $28^{\prime} 44^{\prime \prime} \mathrm{N}$ 6108'52”W], serra Sorocaima II, São Marcos Indigenous Reserve, igarapé unnamed, 5.xi.2007, I. Macuxi; 1 male (61.0:43.0), INPA 845, mun. Alto 
Alegre, Yanomami Indigenous Reserve, rio Auaris,

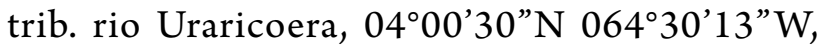
approximately $800 \mathrm{~m}$ elev., 3.iii.1994, V. Py-Daniel et al.; 1 male (60.8:40.8), MZUSP 15066, mun. Amajari, rio Uraricoera, furo Maracá $03^{\circ} 21^{\prime} 04.57^{\prime} \mathrm{N}$ 061²5’21.26”W, 26.iii.1987, V. Py-Daniel et al.; 4 males (61.1:40.3-85.0:56.4), 4 females (62.0:41.284.5:55.3), INPA 848, mun. Alto Alegre, Yanomami Indigenous Reserve, rio Uraricoera basin, unnamed stream, Community Palimi-ú, 0320'03”N 062 58'16”W, 210 m elev., 22.v.1995, V. Py-Daniel and U.C. Barbosa; 1 male, 1 female, IVIC 1097, idem; 3 males (63.3:41.2-78.1:50.6) 3 females (66.5.4:43.774.7:49.4), INPA 849, mun. Alto Alegre, Yanomami Indigenous Reserve, rio Parima basin, rio Warapekt-ú, PIN Xitei/Xidea, 0240’18”N 06349'52”W, 960 m elev., 7.x.1997, leg. U.C. Barbosa; 2 males (74.8:48.9; 84.3:55.4), 1 female (73.2:44.0), INPA 1252, mun. Alto Alegre, Yanomami Indigenous Reserve, rio Parima, Community Watatas, $750 \mathrm{~m}$ elev., PIN Xitei/ Xidea, 02³6’29”N 06352'18”W, 18.ix.2002, leg. V. Py-Daniel et al.; 2 males (64.3:42.2; 71.4:47.1), INPA 843, idem locality, 6.xii.1997, G. Vela; 1 male (broken), 2 females (66.1:43.2; 74.3:49.2), INPA 844, idem locality, 13.iv.1997, G. Vela; 1 male (83.0:54.8), 2 females (84.4:55.6; 90.4:59.8), INPA 846, idem locality, x.1998, V. Py-Daniel et al.; 1 male (74.5:48.5), 1 female (86.4:56.6), INPA 847; 1 male, 1 female (57.6:37.6), CNCR 26496; 1 male (65.8:42.3), 1 female (75.7:49.8), SMF 31364; 1 male (72.4:48.5), 1 female (64.5:43.2), MZUSP 13903; mun. Alto Alegre, Yanomami Indigenous Reserve, rio Parima basin, rio Karrucimabi-ú (trib. rio Kunemari), PIN Xitei/Xidea, 02³4'09”N 06350’37”W, 1020 m elev., 12.viii.1997, V. Py-Daniel et al.; 1 male (76.5:48.7), INPA 1247, rio Branco, rocky area downstream from the mouth of rio Mucajaí (02¹9’00”N 06050’00”W), 11.iv.1997, leg. V. Kowalczuk.

Distribution. Venezuela, Brazil (Roraima) (Rodríguez and Suárez, 1994; Mora-Day and BlancoBelmonte, 2008; this study).

Remarks. The gonopods of the specimens from Roraima (Fig. 1G) show a high morphological similarity with that of the holotype as described in Rodríguez and Suárez (1994) and figured in Rodríguez and Campos (1998: 766, fig. 2A, B) and no remarkable variation was noticed.

With the present records, F. stenolobus exhibits a somewhat wide distribution that encompasses both the Amazonian and Orinocoan slopes of the Serra Paracarima. On the Venezuelan side, the species is distributed in the contiguous hydrographic basins of the Caura River (Rodríguez and Suárez, 1994; Magalhães and Pereira, 2003) and in the Paragua River (Mora-Day and Blanco-Belmonte, 2008). On the Brazilian side, it seems to be relatively frequent in the more elevated areas (above $750 \mathrm{~m}$ ) of the upper Uraricoera River and upper Surumu River basins, but also occurring at lower elevations in the middle course of the Branco River after its confluence with the Mucajaí River (lower than 100 m) (Fig. 4).

\section{Genus Kingsleya Ortmann, 1897}

\section{Kingsleya latifrons (Randall, 1840) \\ (Figs. 1H, 4)}

Previous records. Magalhães (1986: 615); Magalhães (1998: 518, in catalogue); Magalhães (2003: 184, in map); Magalhães and Pereira (2007: 123, in table 3 - listed under Amazon basin, 124, in table 4 - listed under Negro River basin).

Material examined. BRAZIL, Roraima: 2 males (51.0:33.0; 52.0:33.3), 2 females (57.0:36.8; 65.3:41.2), MZUSP 6390, Surumu (04¹1'35”N 06047’35”W), date and leg. unknown; 1 male (42.0:25.9), INPA 1248, mun. Bonfim, rio Tacutu (0322'51"N 059 48'40”W), 26.iii.1992, J. Zuanon and J.A. Gomes; 1 male (31.4:20.7) 1 female (24.6:16.0), INPA 1249, mun. Bonfim, igarapé Arraia, approximately $8 \mathrm{~km}$ before Bonfim, under the bridge (0321'21"N $\left.059^{\circ} 54^{\prime} 13^{\prime \prime} \mathrm{W}\right)$, 25.iii.1992, J. Zuanon; 1 male (53.9:34.0), 2 females, MIRR 75, mun. Bonfim, urban center, rio Tacutu (03²1'20”N 05949'51”W), 27.iii.2010, F. Zanetti and P.R.P. Andrade; 1 male, MIRR 99, mun. Bonfim, urban center, rio Tacutu (032 $\left.1^{\prime} 20^{\prime} \mathrm{N} 059^{\circ} 49^{\prime} 51^{\prime \prime} \mathrm{W}\right)$, 12.iii.2011, P.R.P. Andrade; 2 males, 7 females, INPA 2430) mun. Bonfim, urban center, rio Tacutu (0321'14.8”N 05949'57.4”W), 07.iv.2015, F. Zanetti and S.C. Emídio; 4 males, 3 females, INPA 2433, mun. São Luiz do Anauá, rio Anauá, vicinal $21\left(01^{\circ} 07^{\prime} \mathrm{N}\right.$ 
06000’W), 31.i.2015, F. Zanetti, M.A.L. Santos; I. R. Almeida and S.C. Emidio; 3 males, 6 females (1 ov.), INPA 2439, mun. São Luiz do Anauá, igarapé São Luizão, vicinal 21 (0105’ N 06000’W), 31.i.2015, F. Zanetti, M.A.L. Santos, I.R. Almeida and S.C. Emidio; 2 males, 1 female, INPA 2436, mun. São João da Baliza, vicinal 28 , unnamed igarapé $\left(00^{\circ} 55^{\prime} \mathrm{N} 059^{\circ} 52^{\prime} \mathrm{W}\right)$, 29.iv.2015, F. Zanetti, M.A.L. Santos, S.C. Emidio and P.M. Castro; 5 males, 8 females, INPA 2441, mun. Caroebe, sítio Sumaúma, rio Caroebe $\left(00^{\circ} 50^{\prime} \mathrm{N}\right.$ 05942’W), 03.ii.2015, F. Zanetti, M.A.L. Santos, I.R. Almeida and S.C. Emidio; 4 males, 2 females, INPA 2432 , mun. Caroebe, rio Jatapú, Entre Rios $\left(00^{\circ} 45^{\prime} \mathrm{N}\right.$ $\left.059^{\circ} 17^{\prime} \mathrm{W}\right)$, 02.ii.2015, F. Zanetti, M.A.L. Santos, I.R. Almeida and S.C. Emidio; 2 males (57.6:34.8; 49.5:30.4), 1 female (69.5:41.6), INPA 2411, mun. São Luiz do Anauá, rio dos Peixes, fazenda Água Limpa $\left(00^{\circ} 41^{\prime} \mathrm{N} 060^{\circ} 11^{\prime} \mathrm{W}\right)$, 05.ii.2015, F. Zanetti, M.A.L. Santos, I.R. Almeida and S.C. Emidio; 2 immat. males, 4 immat. females, INPA 2438, mun. Caroebe, vicinal 35, igarapé Taboca $\left(00^{\circ} 35^{\prime} \mathrm{N} 059^{\circ} 43^{\prime} \mathrm{W}\right), 03$.ii.2015, F. Zanetti, M.A.L. Santos, I.R. Almeida and S.C. Emidio.

Distribution. Guyana, Suriname, French Guyana, Brazil (Amapá, Amazonas, Pará, Roraima) (Holthuis, 1959; 1993; Rodriguez, 1982; Magalhães, 1986; 2003; Vieira, 2008; this study).

Remarks. The G1s of the specimens studied herein from the Tacutu River (Fig. 1H) exhibit an overall resemblance with the $\mathrm{G} 1$ of the specimen from the Surumu River figured by Magalhães (1986: 629, fig. $8)$. However, some of the specimens from the Jatapu River basin, in southeastern Roraima have a G1 with more longitudinally straight apical plate, resembling those from the Uatumã River basin (Magalhães, 1986: 629, figs. 9, 10).

The species has a broad distribution that includes several rivers draining both slopes of the Guyana Shield in Brazil (east from the Branco River basin in Roraima to the western portion of the state of Amapá), Guyana, Suriname and French Guiana (Holthuis, 1959; 1993; Rodriguez, 1982; Magalhães, 1986; 2003; Vieira, 2008; this study). The species is typically found in the upper course of the rivers, usually inhabiting fast flowing, lotic waters with rocky bottoms of rapids and falls (Magalhães, 1986, 2003; Holthuis, 1993).

\section{Trichodactylidae H. Milne Edwards, 1853}

\section{Genus Moreirocarcinus \\ Magalhães and Türkay, 1996}

\section{Moreirocarcinus laevifrons (Moreira, 1901) \\ (Figs. 2A, 5)}

Material examined. BRAZIL, Roraima: 6 males, 4 females, MIRR 7, mun. Caracaraí, PARNA Viruá (0142’25”N 06110’24”W), 28.vii.2006, L.F.R. Guterres and P.M. Castro; 1 male, 1 female, MIRR 4, idem locality, 5.iii.2006, L.F.R. Guterres and P.M. Castro; 5 males, MIRR 23, mun. Caracaraí, Perdida road, igarapé Bueiro, 01²5’16”N 06059'17”W, 21.v.2007, L.F.R. Guterres and P.M. Castro; 1 male (20.6:16.4), INPA 1760, mun. Caracaraí, PARNA Viruá, igarapé Espelho, 01²1'51.8”N 06058'54.2”W, 11.iv.2007, L. Rapp Py-Daniel; 1 male (16.7:13.2), 4 females (16.7:12.9-23.0:17.6), 2 male abdomens with gonopods, INPA 1904, mun. Caracaraí, PARNA Viruá, Pallial track, 0114’36”N 061¹7'29”W, 24.v.2007, T. Carvallis and F.A.D. Esteves; 2 males (24.4:19.0; 24.6:18.6), INPA 1493, mun. Caracaraí, rio Anauá, igarapé Defrento, 0059'56”N 06106’16”W, 24.ix.2006, L. Rapp Py-Daniel.

Distribution. Venezuela, Colombia, Brazil (Amazonas, Roraima [new record]) (Magalhães, 2003; Campos, 2002; 2005; 2014; this study).

Remarks. This species is easily recognized by the orbicular carapace with lateral margins bearing 7-8 acute teeth and frontal margin bilobed, smooth. The G1 is slender, distally straight and regularly tapering. The apex is narrow and assymetrical, with its mesiodistal border being slightly shorter than the latero-distal border (Fig. 2A).

The species is mainly distributed in the Amazon River and Orinoco River basins in Brazil, Colombia, and Venezuela (Magalhães, 2003; Campos, 2002; $2005 ; 2014)$. In the Brazilian territory, it was only known in the state of Amazonas, in the Negro River basin (Magalhães, 2003). The above records show that it also occurs in the Branco River basin and constitute the first report of the species in the state of Roraima (Fig. 5). 


\section{Poppiana dentata (Randall, 1840)}

(Figs. 2B, 5)

Previous records. Magalhães (2003: 230, fig. 124, in map); Magalhães and Pereira (2007: 124, in table 4 - listed under Negro River basin); Magalhães and Türkay (2008: 198).

Material examined. BRAZIL, Roraima: 4 juv. males (11.3:9.3-17.3:14.0), 2 juv. females (11.7:9.9; 13.2:10.7), INPA 1251, mun. Amajarí, rio Uraricoera, ilha de Maracá $\left(03^{\circ} 21^{\prime} 07^{\prime} \mathrm{N} 061^{\circ} 25^{\prime} 22^{\prime}\right.$ W), igarapé unnamed, 5.vii.1995, V. Kowalczuk; 1 male (32.4:26.3), INPA 1896, mun. Amajarí, rio Uraricoera, Maracá

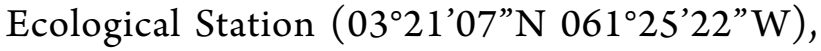
14.iii.2008, leg. uknown; 1 male (21.3:17.7), INPA 2412, mun. Amajarí, rio Uraricoera, Maracá Ecological Station, 03²1'13.6”N 061 29'45.0"W, 4.vi.2008, coll. unknown; 2 males (30.0:24.4; 41.9:33.2), 2 females (33.1:26.3; 38.8:30.7), MIRR 10, mun. Bonfim, igarapé Fogo, vila Vilhena (0321'01"N 059 52'41"W), 6.viii.2006, D. Coscarelli; 1 male (28.0:22.4; 30.7:23.2), MIRR 102, mun. Mucajaí, rio Mucajaí, vicinal Lago, vila Tamandaré, (02³4'53”N 06058’00”W), 4.ix.2011, F. Zanetti, T.E. Sousa and S.C.Emidio; 1 male (46.7:37.3), MNRJ 8711, rio Mucajaí (02²6’13”N 06052’10”W), 19-21.ix.1986, C.F.S. Menezes.

Distribution. Nicaragua, Trinidad, Venezuela, Guyana, Suriname, French Guiana, Colombia, Brazil (Roraima, Amazonas) (Magalhães, 2003; Magalhães and Türkay, 2008; Campos, 2005; 2014; Pereira and García, 2006; this study).

Remarks. With respect to the carapace morphology, P. dentata highly resembles M. laevifrons. However, both species can be readily distinguished by the spined (in P. dentata) or smooth (M. laevifrons) frontal margin. The morphology of the G1 of the specimens studied herein (Fig. 2B) is very similar to the description and illustrations offered by Magalhães and Türkay (2008).

Poppiana dentata has a very wide distribution in northern South America, occurring in the Orinoco River basin and in several coastal river basins from French Guiana to Colombia, as well as on the island of Trinidad and in Nicaragua (Campos, 2005; 2014; Magalhães and Türkay, 2008). The distribution of the species in the Amazon River basin seems to be restricted to the Branco River basin, in Roraima (Fig. 5), and the upper Negro River basin, in Amazonas (Magalhães and Türkay, 2008; this study).

\section{Sylviocarcinus pictus (H. Milne Edwards, 1853)}

$$
\text { (Figs. 2C, 6) }
$$

Previous records. Magalhães and Türkay (1996b: 117, fig. 38, in map); Magalhães (1998: 520, in catalogue); Magalhães (2003: 244, fig. 134, in map); Magalhães and Pereira (2007: 124, in table 4 - listed under Negro River basin); Castro and Silva (2013: 42, in table 1).

Material examined. BRAZIL, Roraima: 1 male, INPA 2425, mun. Amajari, rio Ereú, $04^{\circ} 02^{\prime} \mathrm{N} 061^{\circ} 23^{\prime} \mathrm{W}$, 16.iv.2014, F. Zanetti and M.A.L. Santos; 2 females, INPA 1901, mun. Normandia, Rio Maú, 0352’23,6”N 059³6’11,8”W, 20.iii.2010, V. Py-Daniel, U.C. Barbosa and O.S. Silva; 1 male, 1 female, INPA 1903, mun. Amajari, rio Coimim, downstream from confluence with rio Érico (03³9’40”N 062²7’35”W), 01.ix.1987, V.Py-Daniel and U.C. Barbosa; 1 immat. female, MIRR 41, mun. Amajarí [0339'11”N 061²2’17”W], road to Tepequém, 1.v.2009, leg. L.F. Guterres, P.M. Castro, F.C. Zanetti and J.S. Tavares; 1 female, MIRR 41, mun. Amajari [03³9'11”N 061²2'17”W], road to Tepequém, igarapé under the first bridge, 1.v.2009, P.M. Castro; 1 male (41.8:38.0), MIRR 57, mun. Amajarí, rio Trairão, (03³7’49”N 06151'00”W), 6.ix.2009, D.A. Lima; 2 males, 1 female, MIRR 71, mun. Amajarí, igarapé Coimbra, vila Bom Jesus/ Tomás, vicinal II, 0337’ N 061ํ51'W, 31.x.2009, P.M. Castro, D.A. Lima and F. Zanetti; 1 male, 5 females, MIRR 70, mun. Amajarí, igarapé Coimbra, vila Bom Jesus/Tomás, vicinal I, rio Trairão, $03^{\circ} 37^{\prime} \mathrm{N}$ 061 ${ }^{\circ} 51^{\prime}$ W, 31.x.2009, P.M. Castro, D.A. Lima and F. Zanetti; 1 male, 1 immat. female, INPA 2416, mun. Amajarí, rio Trairão, vila Maracá, $03^{\circ} 37^{\prime} 54.2^{\prime \prime} \mathrm{N}$ 06151'41.1”W, 18.iv.2015, F. Zanetti, M.A.L. Santos, J. Santos and J. Bezerra; 1 female, INPA 2415, mun. Amajarí, vila Maracá, Bom Jesus, vicinal II, igarapé Traírinha, 03³5'49.3”N 06146’23.4”W, 18.iv.2015, F. Zanetti, M.A.L. Santos, Santos, J. and J. Bezerra; 1 male, 1 female, INPA 2428, mun. Bonfim, rio Tacutu, road to Normandia, $03^{\circ} 33^{\prime} \mathrm{N} 059^{\circ} 53^{\prime} \mathrm{W}$, 18.iv.2014, M.A.L. Santos; 1 male, INPA 1897, mun. Alto Alegre, rio Uraricoera, Yanomami Indigenous Reserve, PIN Waikás, 03³2'58”N 06310'11”W, 23.v.1987, V. PyDaniel and U.C. Barbosa; 1 male, 1 female, MIRR 
67, mun. Amajarí, serra Tepequém, SESC Ecological Station, $03^{\circ} 27^{\prime} \mathrm{N} 061^{\circ} 41^{\prime}$ W, 30.x.2009, P.M. Castro and R.D. Souza; 2 males, 2 females, MIRR 46, mun. Bonfim, urban center, rio Tacutu $\left(03^{\circ} 21^{\prime} 20^{\prime} \mathrm{N} 059^{\circ} 49^{\prime} 51^{\prime \prime} \mathrm{W}\right)$, 30.v.2009, A.M. Silva, F.S. Pinto and P.R.P. Andrade; 2 males, MIRR 38, mun. Bonfim, urban center, rio Tacutu (0321'20”N 05949'51”W), 15.iv.2009, A.M. Silva, F.S. Pinto and P.R.P. Andrade; 3 females, MIRR 34, mun. Bonfim, urban center, rio Tacutu (03²1'20”N 05949'51”W), 28.ii.2009, A.M. Silva, F.S. Pinto and P.R.P. Andrade; 2 males, MIRR 33, mun. Bonfim, rio Tacutu, 0321'19”N 05949'56”W, 15.iv.2009, A. Mariza and P. Ricardo; 2 males, 1 female, INPA 2418, mun. Bonfim, rio Tacutu, 03²1'14.8”N 059 49'57.4” W, 7.iv.2015, F. Zanetti and S.C. Emidio; 3 males 1 female, INPA 1899, mun. Alto Alegre, Yanomami Indigenous Reserve, rio Uraricoera, PIN Palimi-ú, 0320’03”N 06258'16”W, 24.v.1987, V. PyDaniel and U.C. Barbosa; 1 male, MIRR 18, mun. Boa Vista, Passarão, mouth of igarapé Cajual ( $03^{\circ} 10^{\prime} 49^{\prime} \mathrm{N}$ 060³3’14”W), 11.xi.2006, M.R.C. Barreto-Netto; 1 male, INPA 1902, mun. Bonfim, igarapé Surrão, BR 401 road, 02 $51^{\prime} 46,4$ ”N 060³3’32,0”W, 21.iii.2010, V. Py-Daniel, U.C. Barbosa and O.S. Silva; 1 male, MIRR 14, mun. Boa Vista [0249’02”N 060³9'54”W], igarapé Branco, EMBRAPA region, 8.x.2006, W.R. Souza; 4 males, INPA 2431, mun. Mucajaí, vila Tamandaré, vicinal Tronco, $\mathrm{km} \mathrm{15}$, igarapé unnamed, 02³4'53”N 06058'00”W, 11.i.2015, F. Zanetti, T.E. Souza, T.E. Souza and I.Z. Emidio; 2 males, MIRR 65 , mun. Mucajaí, vila Tamandaré $\left(02^{\circ} 34^{\prime} 45^{\prime} \mathrm{N}\right.$ 06058’08”W), igarapé Raimundo, 10.x.2009, S.C. Emídio; 2 males, 1 female, INPA 1898; mun. Cantá, rio Quitauaú, Confiança $\left(02^{\circ} 34^{\prime} 05^{\prime} \mathrm{N} 060^{\circ} 38^{\prime} 09^{\prime} \mathrm{W}\right)$, 18.iii.1992, J. Zuanon and J.A.A. Gomes; 1 male, MIRR 36, mun. Mucajaí, rio Mucajaí, $2 \mathrm{~km}$ upstream from bridge on road Mucajaí-Boa Vista ( $02^{\circ} 33^{\prime} 47^{\prime \prime} \mathrm{N}$ 06055’43”W), 7.xii.2008, W.R. Souza; 2 females, MIRR 54, mun. Mucajaí, igarapé Arraia, Apiaú region, vicinal I $\left(02^{\circ} 27^{\prime} 23^{\prime} \mathrm{N} 060^{\circ} 56^{\prime 2} 29^{\prime} \mathrm{W}\right)$, 29.viii.2009, D.A.Lima, F. Zanetti and A.S. Sales; 1 male, MIRR 2, mun. Mucajaí, igarapé Sumaúma, sítio Três Irmãos, Rufina region, $02^{\circ} 26^{\prime} 27.50^{\prime} \mathrm{N} 060^{\circ} 56^{\prime} 17.06^{\prime} \mathrm{W}$, 05.xi.2006, L.F.R. Guterres and P.M. Castro; 4 males, 2 females, MIRR 56, mun. Mucajaí, fazenda Tamandaré, igarapé Perdido, Apiaú region, vicinal I, $02^{\circ} 26^{\prime} 27.50^{\prime} \mathrm{N} 060^{\circ} 56^{\prime} 17.06^{\prime}$ W, 29.viii.2009, D.A.
Lima, F. Zanetti, C.S. Rufino and B.E. Lima; 1 male, 1 female, MIRR 79, mun. Mucajaí, fazenda Tamandaré, igarapé Perdido, Apiaú region, vicinal I, $02^{\circ} 26$ '27.50”N 06056 17.06” W, 28.viii.2010, P.M. Castro, Otaviano, A., D.A. Lima, F. Zanetti and Tavares, J.S.; 4 males, 3 females, MIRR 80, mun. Mucajaí, fazenda Tamandaré, igarapé Perdido, Apiaú region, vicinal I, 02²6’27.50”N 06056'17.06”'W, 28.viii.2010, P.M. Castro, Otaviano, A., D.A. Lima, F. Zanetti and Tavares, J.S.; 1 female , MIRR 81, mun. Mucajaí, fazenda Tamandaré, igarapé Perdido, Apiaú region, vicinal I, 02 $26^{\circ} 27.50^{\prime} \mathrm{N}$ 06056'17.06”'W, 28.viii.2010, P.M. Castro, Otaviano, A., D.A. Lima, F. Zanetti and Tavares, J.S.; 3 males, MIRR 53, mun. Mucajaí, igarapé Perdido, Apiaú region, vicinal I, 02²6’27.50”N 06056'17.06”'W, 28.viii.2009, P.M. Castro, D.A. Lima and F. Zanetti; 3 males immat., MIRR 58, mun. Mucajaí, igarapé Perdido, Apiaú region, vicinal I, 02²6’27.50” N 06056’17.06”'W, 19.ix.2009, D.A. Lima, F. Zanetti and J.S. Tavares; 1 female, MIRR 59, mun. Mucajaí, igarapé Perdido, Apiaú region, vicinal I, 02²6’27.50”N 06056'17.06”W, 19.ix.2009, D.A. Lima, F. Zanetti, J.S. Tavares and A.S. Sales; 1 male, 1 female, INPA 2417, mun. Cantá, fazenda Laçador, Açude, $02^{\circ} 07^{\prime} \mathrm{N} 060^{\circ} 50^{\prime}$ W, 24.v.2015, M.G.S. Silva and F.P.L. Santos; 1 male (40.3:36.0), INPA 1900, mun. Caracaraí [01\%49'04”N 061 07'32”W], BR-174 road, km 530, 12.xi.2005, E. Ferreira; 3 males, INPA 2427, mun. São Luiz do Anauá, vicinal 21, igarapé São Luizão, $01^{\circ} 05^{\prime} \mathrm{N} 060^{\circ} 00^{\prime} \mathrm{W}, 31 . i .2015$, F. Zanetti, M.A.L. Santos, I.R. Almeida and S.C. Emidio; 1 immat. male, INPA 2414, mun. Caracaraí, Barrento, rio Xeriuiní, lower rio Branco, 0051'N 061'57’ W, 25.iii.2014, F. Zanetti and M.A.L. Santos; 1 female, INPA 2421, mun. Caroebe, rio Caroebe, sítio Sumaúma, 0050’44.2”N 059²'23.7”W, 03.ii.2015, F. Zanetti, M.A.L. Santos, I.R. Almeida and S.C. Emidio; 1 male (42.7:37.7), INPA 2426, mun. São João da Baliza, rio Mata Fome, vicinal 26, 0040’ $060^{\circ} 03^{\prime} \mathrm{W}, 28$.iv.2015, F. Zanetti, M.A.L. Santos, S.C. Emidio and P.M. Castro; 11 males, 7 females, INPA 2429, mun. Caroebe, Entre Rios, vicinal 13, igarapé Espanta Moleque, $00^{\circ} 35^{\prime} \mathrm{N}$ 05943’W, 2.ii.2015, F. Zanetti, M.A.L. Santos, I.R. Almeida and S.C. Emidio; 3 males ( 1 ad., 2 immat.), 3 immat. females, INPA 2424, mun. Caroebe, vicinal 35, igarapé Taboca, $00^{\circ} 35^{\prime} \mathrm{N} 059^{\circ} 43^{\prime} \mathrm{W}, 03 . i i .2015$, F. Zanetti, M.A.L. Santos, I.R. Almeida and S.C. Emidio; 2 males, 2 females, INPA 2419, mun. Rorainópolis, left 
bank of rio Jauaperi, $00^{\circ} 31^{\prime} \mathrm{N} 060^{\circ} 27^{\prime} \mathrm{W}$, 29.iv.2015, F. Zanetti, M.A.L. Santos, S.C. Emidio and P.M. Castro; 6 males, 4 females, INPA 2423, mun. Caracaraí, paranã Preguiça, lower rio Branco, 00²9’N 061³9'W, 27.iii.2014, F. Zanetti and M.A.L. Santos.

Distribution. Venezuela, Guyana, French Guiana, Colombia, Peru, Bolivia, Brazil (Amapá, Amazonas, Pará, Maranhão, Piauí, Rondônia, Roraima) (Magalhães and Türkay, 1996b; Mora-Day et al., 2008). Additional records of the species in the state of Roraima were presented by Magalhães and Türkay (1996) from the Surumu and Branco Rivers.

Remarks. The G1s of the specimens studied herein (Fig. 2C) are morphological highly similar to the G1 described and illustrated by Magalhães and Türkay (1996b).

Sylviocarcinus pictus is one of the most common and widespread species of Trichodactylidae, occurring in the Amazon River basin and in coastal river basins of northern South America, in Venezuela, Guyana and French Guiana (Magalhães and Türkay, 1996b; Mora-Day et al., 2008). It is also broadly distributed in Roraima (Fig. 6). The species has been recorded from both slopes of the Serra Pacaraima and Serra Acari, with occurences in the Cuyuni River (Mora-Day et al., 2008), Rupununi River (Magalhães and Türkay, 1996b), and upper Essequibo River (Lasso et al., 2008) basins on the Venezuelan and Guyanan sides, and in the Branco River and Jauaperi River, Uatumã River and Trombetas River basins (Magalhães and Türkay, 1996b; this study) on the Brazilian side. However, it does not occur in tributaries of the Orinoco River with headwaters in the Guyana Shield as suggested by its absence in surveys recently done in some river basins of this region (Magalhães and Pereira, 2003; Pereira and García, 2006; Mora-Day and Blanco-Belmonte, 2008; Mora-Day et al., 2008).

\section{Genus Valdivia White, 1847}

\section{Valdivia serrata White, 1847 \\ (Figs. 2D, 7)}

Previous records. Castro and Silva (2013: 42, in table 1).
Material examined. BRAZIL, Roraima: 1 male, 2 females, INPA 2442, Pacaraima, BR 174 road, km

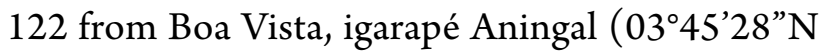
060 59'10”W), 30.xi.1988, coll. unknown; 1 male (29.3:24.5), INPA 1295, mun. Amajari, igarapé Mani $\left(03^{\circ} 24^{\prime} 02^{\prime \prime} \mathrm{N} 063^{\circ} 01^{\prime} 49^{\prime} \mathrm{W}\right)$, trib. of rio Uraricoera, 23.v.1987, V. Py-Daniel and U.C. Barbosa; 1 immat. male (damaged), INPA 1906, mun. Amajarí, rio Uraricoera, Maracá Ecological Station, 032 1'13.6” N 061 29'45.0”W, coll. unknown; 1 male, MIRR 19, mun. Boa Vista, Passarão, mouth of igarapé Cajual (0310'49”N 060³3'14”W), 11.xi.2006, M.R.C.Barreto-Netto; 1 immat. female, MIRR 87, mun. Boa Vista [0250’19”N 06044'13”W], rio Cauamé, praia Caçari, 08.x.2010, A.A. Otaviano, F. Zanetti and R. Serafim; 3 females, MIRR 92, mun. Boa Vista [0250'19” N 06044'13”'W], rio Cauamé, praia Caçari, 31.i.2011, A.A. Otaviano, F. Zanetti and R. Serafim; 1 immat. male, MIRR 49, mun. Mucajaí, Roxinho, igarapé Mota, 02²0’33.8”N 061¹0'17.6”W, 25.viii.2009, J.S. Tavares and L.F.R. Guterres; 1 immat. male, MIRR 51, mun. Mucajaí, Roxinho, igarapé Mota, $02^{\circ} 20^{\prime} 33.8^{\prime} \mathrm{N}$ $061^{\circ} 10^{\prime} 17.6$ ”W, 25.viii.2009, J.S. Tavares and L.F.R. Guterres; 1 immat. male, MIRR 52, mun. Mucajaí, Roxinho, igarapé Mota, $02^{\circ} 20^{\prime} 33.8^{\prime} \mathrm{N} 061^{\circ} 10^{\prime} 17.6$ ”W, 25.viii.2009, J.S. Tavares and L.F.R. Guterres; 1 immat. male, MIRR 61, mun. Mucajaí, Roxinho, igarapé Mota, 02²0’33.8”N 061¹0'17.6”W, 5.x.2009, J.S. Tavares and L.F.R. Guterres; 1 immat. male, MIRR 62, mun. Mucajaí, Roxinho, igarapé Mota, $02^{\circ} 20^{\prime} 33.8^{\prime} \mathrm{N}$ 061 10'17.6”W, 05.x.2009, J.S. Tavares and L.F.R. Guterres; 1 immat. male, MIRR 63, mun. Mucajaí, Roxinho, igarapé Mota, 02²0’33.8”N 061¹0'17.6”W, 5.x.2009, J.S. Tavares and L.F.R. Guterres; 1 immat. male, INPA 1905, mun. Iracema, Yanomami Indigenous Reserve, rio Ajaraní, PIN Ajaraní, 0159'51”N 06130'40”'W, 3.iii.1999, V. Py-Daniel, U.C. Barbosa and O.S. Silva; 12 males (1 ad., 11 immat. or juv.), 8 females ( 1 ad., 7 immat.), INPA 2444, mun. Caracaraí,

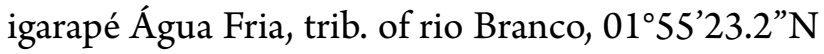
06100’29.1”W, 19.ix.2011, L.H. Rapp Py-Daniel, R. Ribeiro, M. de Pinna and A. Oliveira; 1 immat. male, 6 immat. females, INPA 1487, mun. Caracaraí, BR 174

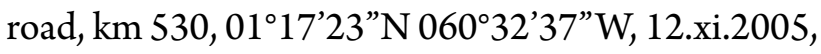
E. Ferreira et al.; 6 males, 5 females, MIRR 5, mun. Caracaraí, PARNA Viruá (0142’25”N 061¹0’24”W), 05.iii.2006, L.F.R. Guterres and P.M. Castro; 1 male, 
MIRR 8, mun. Caracaraí, PARNA Viruá $\left(01^{\circ} 42 ’ 25^{\prime} \mathrm{N}\right.$ 061 ${ }^{\circ} 10^{\prime 2}$ " 'W), 28.vii.2006, L.F.R. Guterres and P.M. Castro; 1 male (37.5:31.0), INPA 1505, mun. Caracaraí, rio Branco, PARNA Viruá (0142’25”N 061¹0’24”W), 01.vi.2006, J.Zuanon et al.; 1 male (48.9:36.2), 1 female (56.3:47.6), INPA 2443, mun. Caracaraí, PARNA

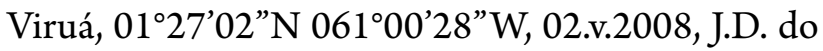
Vale; 1 male, MIRR 3, mun. Caracaraí, Perdida road, igarapé Bueiro, 01²5’16”N 06059’17”W, 4.iii.2006, L.F.R. Guterres and P.M. Castro, 1 male, MIRR 11, mun. Caracaraí, Perdida road, igarapé Bueiro, $01^{\circ} 25^{\prime} 16^{\prime \prime} \mathrm{N}$ 06059'17”W, 31.viii.2006, L.F.R. Guterres and P.M. Castro; 2 males, MIRR 12, mun. Caracaraí, Perdida road, igarapé Bueiro, 01²5’16”N 06059'17”W, 31.viii.2006, L.F.R. Guterres and P.M. Castro; 32 immat. males, 5 females immat., MIRR 13, mun. Caracaraí, Perdida road, igarapé Bueiro, $01^{\circ} 25^{\prime} 16^{\prime \prime} \mathrm{N}$ 06059'17”W, 20.ix.2006, L.F.R. Guterres and P.M. Castro; 3 male, MIRR 15, mun. Caracaraí, Perdida road, igarapé Bueiro, $01^{\circ} 25^{\prime} 16^{\prime} \mathrm{N} 060^{\circ} 59^{\prime} 17^{\prime} \mathrm{W}$, 14.x.2006, L.F.R. Guterres and P.M. Castro; 1 male, MIRR 17, mun. Caracaraí, Perdida road, igarapé Bueiro, 01²5'16”N 06059'17”W, 19.x.2006, L.F.R. Guterres and P.M. Castro; 4 males, MIRR 28, mun. Caracaraí, Perdida road, igarapé Bueiro, $01^{\circ} 25^{\prime} 16^{\prime \prime} \mathrm{N}$ 060 59'17”'W, 4.xi.2007, L.F.R. Guterres and P.M. Castro; 1 male, 4 immat. males, 4 immat. females, MIRR25, mun. Caracaraí, Perdida road, igarapé Bueiro, 01²5'16”N 060'59'17”W, 4.ix.2007, L.F.R. Guterres and E.S. Marinho; 1 immat. male, 1 female, INPA 2422, mun. São João da Baliza, rio Mata Fome, vicinal 26, 0040’N 06003’W, 28.iv.2015, F. Zanetti, M.A.L. Santos, S.C. Emidio and P.M. Castro; 3 females, INPA 2413, mun. Caroebe, Entre Rios, vicinal 13, igarapé “Espanta Moleque”, 00³5’N 05943’W, 2.ii.2015, F. Zanetti, M.A.L. Santos, I.R. Almeida and S.C. Emidio.

Distribution. Venezuela, Suriname, Ecuador, Peru, Colombia, Brazil (Acre, Amazonas, Maranhão, Pará, Rondônia, Roraima), Bolívia (Holthuis, 1959; Rodríguez, 1992; Magalhães, 2002; 2003; 2005; Vieira, 2008; Castro and Silva, 2013; Campos, 2014; this study).

Remarks. The taxonomic status of V. serrata and related forms (Magalhães and Türkay, 1996a) is not yet settled due to a considerable amount of variability found either in somatic or gonopodal characters (C. Magalhães, unpubl. data). Most of the male specimens studied herein are immature or subadults. As such, the gonopod morphology could not be adequately evaluated. However, in the few fully-grown adults examined, the $\mathrm{G} 1$ shows the distal portin moderately curved (approximately $40-45^{\circ}$ ) in ventro-lateral direction, with its margins nearly subparallel; the subterminal field of spines is well developed and the ventral border has a distinct subretangular, median lobe (Fig. 2D).

The present species has a very broad distribution throughout the entire Amazon River and Orinoco River basins as well as in the coastal river basins of northern South America, but has only recently been reported in the state of Roraima (Castro and Silva, 2013). The above records show that it is also well distributed in the state, occurring mainly in the lowland portion of the Branco River, Jauaperi River and Jatapu River basins (Fig. 7).

\section{Discussion}

All ten species of freshwater crabs that are reported herein from the state of Roraima are distributed in the Branco River basin, although $K$. latifrons, S. pictus and $V$. serrata can also occur in the Jauaperi River and Jatapu River basins (Figs. 3-7). The pseudothelphusid species are usually associated with rivers originating in the mountainouns regions along the border with Venezuela and Guyana in the northwestern (Serra Paraima), northern and northeastern (Serra Pacaraima), and the southeastern portion of the state (Serra Acaraí) (Figs. 3-4), although F. stenolobus can also be found in lower regions along the upper Branco River (Fig. 4). On the other hand, the trichodactylid species are mainly distributed in lower elevation areas along the Branco River and its tributaries, Uraricoera River and Tacutu River (Figs. 5-7), but S. pictus can also occur at higher elevations such as in some tributaries of the Uraricoera River coming from the Serra Pacaraima (Fig. 6). This general altitudinal distribution of representatives of both families in Roraima is in accordance with the zoogeographic division of the Neotropical freshwater decapod fauna mentioned by Rodriguez (1981).

Pseudothelphusidae is slightly richer in species than Trichodactylidae (six vs four) in Roraima, but these numbers may be somewhat underestimated for 
both families. The more elevated regions along the mountainous areas in the northern and western part of the state are either protected areas or indigenous reserves (EPE, 2010), which makes biological surveys more difficult to conduct in these areas. As a mountainous group, the number of pseudothelphusids might be greater considering that large portions of this territory have not yet been sufficiently explored for decapods. For instance, Kunziana irengis (Pretzmann, 1971) occurs in Guyana along the Ireng River and upper Potaro River basins (Magalhães et al., 2009). The Ireng River marks the border between Brazil and Guyana (it is named Maú River on the Brazilian side) and its presence in the northeastern part of the state of Roraima would not be unlikely. Provided they are properly surveyed, some other regions of the state may potentially increase the number of crab species in Roraima as well. This is the case, for instance, in the Serra da Mocidade, which comprises a mountainous complex with up to $1700 \mathrm{~m}$ in elevation, isolated from the Guyana Shield, in the center-western portion of the state. The potential of these isolated mountainous areas in the Amazon region to reveal new pseudothelphusid crabs is high, as indicated by the description of Microthelphusa lipkei Magalhães, 2010 from Serra do Aracá (Magalhães, 2010), also a group of isolated mountains situated in the state of Amazonas close to the border with Roraima, a little to the west of the Serra da Mocidade.

The number of trichodactylid species from Roraima may also be somewhat underestimated. Extensive lowland areas of the lower Branco River are still poorly explored for freshwater crabs (Figs. 5-7). Magalhães and Pereira (2007) listed eight species as occurring in the Negro River, of which the Branco River is the main tributary, and four of them (M. laevifrons, $P$. dentata, $S$. pictus, V. serrata) are also recorded from Roraima henceforth. It would not be unexpected that at least some of the others could also be found in the lower Branco River if more intensive surveys of the area were carried out.

As expected, the species richness of freshwater crabs of the Branco River is lower than that of Negro River, which has a much larger drainage surface and is better surveyed, especially in its lower course. Magalhães and Pereira (2007) listed 10 pseudothelphusids and eight trichodactylids from the Negro River basin, while six and four, respectively, are herein reported from the
Branco River basin. In total, the species richness of crab of the Xingu River basin is higher than that of the Branco River basin (13 vs. 10 species, respectively), but Branco River basin crab fauna is a little richer in pseudothelphusids than Xingu River basin fauna (six vs. five species, respectively). However, Xingu River has more trichodactylids than the Branco River (eight vs four, respectively) (Magalhães et al., unpubl. data). When comparing the total number of species compiled by Magalhães and Pereira (2007) to the sub-basins of the other northern tributaries of the Amazon basin draining the Guyana Shield, the Branco River basin shows higher species richness (Uatumã River: six species; Trombetas River: seven species; Jari River: four species). However, such comparisons should be made with great care as these river basins are very poorly surveyed for decapods.

\section{ACKNOWLEDGeMENTS}

The authors dedicate this contribution to Prof. Dr. Ludwig Buckup (Universidade Federal do Rio Grande do Sul, retired) in recognition of his distinguished career as a zoologist and particularly for his achievements that have greatly contributed to the development of the Brazilian Carcinology both scientifically and in the formation of young scientists. PMC also thanks CNPq for the Research Project 35.0413/2005-3-DCR/ CNPq/FEMACT; FZ and PMC thank the Acordo de Cooperação Técnico-Científica 01280.000370/2011 between INPA, UERR, and IACTI-RR that allowed the accomplishment of the present work. CM thanks the Conselho Nacional de Desenvolvimento Científico e Tecnológico - CNPq for an ongoing Research Scholarship 304736/2015-5, as well as Victor PyDaniel, Ulysses C. Barbosa, and Jansen Zuanon for making the specimens from their collections in Roraima available to this study. The authors are grateful to Douglas Bastos and Priscila Madoka Ito for their kind help with the QGIS software, Colleen M. Flanagan for reviewing the English wording, and two anonymous reviewers for their comments.

\section{References}

Ahyong, S.T.; Lowry, J.K.; Alonso, M.; Bamber, R.N.; Boxshall, G.A.; Castro, P.; Gerken, S.; Karaman, G.S.; Goy, J.W.; Jones, D.S.; Meland, K.; Christopher, D. Rogers and Svavarsson, J. 2011. Subphylum Crustacea Brünnich, 1772. p. 165-191. 
In: Z.-Q. Zhang (ed), Animal biodiversity: An outline of higher-level classification and survey of taxonomic richness. Zootaxa, 3148: 1-237.

Barbosa, R.I.; Ferreira, E.J.G. and Castellón, E.G. (eds). 1997. Homem, Ambiente e Ecologia no Estado de Roraima. Manaus, INPA, 613p.

Bott, R. 1967. Flusskrabben aus Brasilien und benachbarter Gebiete. Potamocarcinus (Kingsleya) Ortmann 1987 (Crustacea, Decapoda). Senckenbergiana biologica, 48: 301312, figs. 1-3.

Calegari, B.B.; Delapieve, M.L.S. and Sousa, L.M. 2016. Tutorial para preparação de mapas de distribuição geográfica. Boletim da Sociedade Brasileira de Ictiologia, 118: 15-30.

Campos, M.R. 2002. Dilocarcinus laevifrons Moreira, 1901: a complete description (Decapoda; Brachyura: Trichodactylidae). Revista de la Academia Colombiana de Ciencias Exactas, Físicas y Naturales, 26: 285-288.

Campos, M.R. 2005. Freshwater crabs from Colombia. A taxonomic and distributional study. Bogotá, Academia Colombiana de Ciencias Exactas Físicas y Naturales. 363p. (Col. Jorge Álvarez Lleras, 24)

Campos, M.R. 2014. Crustáceos decápodos de agua dulce de Colombia. Bogotá, Universidade Nacional de Colombia, Facultad de Ciencias, Instituto de Ciencias Naturales. 691p. (Biblioteca José Jerónimo Triana, 27)

Carvalho, T.M. 2015. Síntese dos aspectos hidrogeomorfológicos do estado de Roraima, Brasil. p. 435-450. In: P. Gorayeb and A. Meiguins (Org), Contribuições à Geologia da Amazônia. Belém, Sociedade brasileira de Geologia, v. 9.

Castro, P. M. and M.R. Silva. 2013. Caranguejos e camarões (Crustacea: Decapoda) do igarapé do Perdido, Apiaú, Mucajaí, Roraima. Boletim do Museu Integrado de Roraima, 7: 40-47.

Coifmann, I. 1939. Potamonidi dell R. Museo Zoologico di Torino. Archivo Zoologico Italiano, 27: 93-116.

Ferreira, E.; Zuanon, J.; Forsberg, B.; Goulding, M. and BrigliaFerreira, S.R. 2007. Rio Branco. Peixes, ecologia e conservação de Roraima. Manaus, Amazon Conservation Association, Instituto Nacional de Pesquisas da Amazônia, Sociedade Civil Mamirauá, 201p.

Goulding, M.; Barthen, R. and Ferreira, E. 2003. The Smithsonian atlas of the Amazon. Washington, D.C. and London, Smithsonian Books, 253p.

Holthuis, L. B. 1959. The Crustacea Decapoda of Suriname. Zoologische Verhandenlingen, 44: 1-296, figs. 1-68.

Holthuis, L.B. 1993. The decapod Crustacea of Brokopondo Lake, Surinam. Nauplius, 1: 1-12.

Huber, O. 1995. Geographical and physical features. p. 1-61. In: P.E. Berry; B.K. Holst and K. Yatskievych (eds), Flora of the Venezuelan Guayana, vol. 1: Introduction. Portland, Timber Press.

Lasso, C.A.; Hernandez-Acevedo, J.; Alexander, E.; Señaris, J.C.; Mesa, L.; Samudio, H.; Mora-Day, J.; Magalhães, C.; Shushu, A.; Mauruwanaru, E. and Shoni, R. 2008. Aquatic biota: fishes, decapod crustaceans and mollusks of the upper Essequibo Basin (Konashen COCA), Southern Guyana. p. 43-54. In:
L.E. Alonso; J. McCullough; P. Naskrecki; E. Alexander and H.E. Wright (Org), A Rapid Biological Assessment of the Konashen Community Owned Conservation Area, Southern Guyana. Arlington, VA, Conservation International. (RAP Bulletin of Biological Assessment, 51)

Lujan, N.K. and Armbruster, J.W. 2011. The Guiana Shield. p. 211224. In: J. Albert and R. Reis (eds), Historical Biogeography of Neotropical Freshwater Fishes. Berkeley, University of California Press.

Magalhães, C. 1986. Revisão taxonômica dos caranguejos de água doce brasileiros da família Pseudothelphusidae (Crustacea, Decapoda). Amazoniana, 9: 609-636.

Magalhães, C. 1998. Malacostraca - Eucarida. Brachyura. Pseudothelphusidae and Trichodactylidae. p. 517-523. In: P. S. Young (ed), Catalogue of Crustaceans of Brasil. Rio de Janeiro, Museu Nacional. [Série Livros, 6]

Magalhães, C. 2002. A rapid assessment of the decapod fauna in the Rio Tahuamanu and Rio Manuripi basins, with new records of shrimps and crabs for Bolivia (Crustacea, Decapoda, Palaemonidae, Sergestidae, Trichodactylidae). Revista brasileira de Zoologia, 19: 1091-1103.

Magalhães, C. 2003. Famílias Pseudothelphusidae e Trichodactylidae.p. 143-287. In: G.A.S. Melo (ed), Manual de Identificação dos Crustacea Decapoda de Água Doce do Brasil. São Paulo, Editora Loyola.

Magalhães, C. 2005. Macrocrustacean survey of selected localities in the Río Pastaza basin in Ecuador and Perú: diversity, habitat, zoogeographical aspects, and conservation implications. p. 67-74. In: P.W. Willink; B. Chernoff and J. McCullough (eds), A rapid biological assessment of the aquatic ecossystems of the Pastaza River basin, Ecuador and Perú. Washington, D.C., Conservation International. (RAP Bulletin of Biological Assessment, 33)

Magalhães, C. 2010. A new species of freshwater crab of the genus Microthelphusa (Decapoda, Pseudothelphusidae) from a tepui in the Serra do Aracá, state of Amazonas, Brazil. p. 453-460. In: C. Fransen; S. De Grave and P. Ng (eds), Studies on Malacostraca: Lipke Bijdeley Holthuis Memorial Volume. Leiden, Brill. (Crustaceana Monographs, 14)

Magalhães, C.; Barbosa, U.C. and Py-Daniel, V. 2006. Decapod crustaceans used as food by the Yanomami Indians of the Balawa-ú village, State of Amazonas, Brazil. Acta Amazonica, 36: 369-374.

Magalhães, C. and Pereira, G. 2003. Decapod crustaceans survey in the middle Río Caura basin: species richness, habitat, zoogeographical aspects, and conservation implications. p. 56-63. In: B. Chernoff; A. Machado-Allison, K. Riseng and J.R. Montambault (eds), A Biological assessment of the aquatic ecosystems of the Rio Caura watershed, Venezuela. Washington, D.C., Conservation International. (RAP Bulletin of Biological Assessment, 28)

Magalhães, C. and Pereira, G. 2007. Assessment of the decapod crustacean diversity in the Guayana Shield region aiming at conservation decisions. Biota Neotropica, 7: 111-124.

Magalhães, C. and Rodríguez, G. 2002. The systematic and biogeographical status of Fredius reflexifrons (Ortmann, 
1897) and Fredius fittkaui (Bott, 1967) (Crustacea: Brachyura: Pseudothelphusidae) from the Amazon and Atlantic Guianas river basins. Acta Amazonica, 32: 677-689.

Magalhães, C.; Sanches, V.Q.A.; Pileggi, L.G. and Mantelatto, F.L. 2014. Morphological and molecular description of a new species of Fredius (Decapoda: Pseudothelphusidae) from Rondônia, southern Amazonia, Brazil. p. 101-114. In: D.C.J. Yeo; N. Cumberlidge and S. Klaus (eds), Advances in Freshwater Decapod Systematics and Biology. Leiden, Brill. (Crustaceana Monographs, 19)

Magalhães, C. and Türkay, M. 1996a. Taxonomy of the Neotropical freshwater crab family Trichodactylidae I. The generic system with description of some new genera (Crustacea: Decapoda: Brachyura). Senckenbergiana biologica, 75: 63-95.

Magalhães, C. and Türkay, M. 1996b. Taxonomy of the Neotropical freshwater crab family Trichodactylidae II. The genera Forsteria, Melocarcinus, Sylviocarcinus, and Zilchiopsis (Crustacea: Decapoda: Brachyura). Senckenbergiana biologica, 75: 97-130.

Magalhães, C. and Türkay, M. 1996c. Taxonomy of the Neotropical freshwater crab family Trichodactylidae III. The genera Fredilocarcinus and Goyazana (Crustacea: Decapoda: Brachyura). Senckenbergiana biologica, 75: 131-142.

Magalhães, C. and Türkay, M. 2008. Taxonomy of the Neotropical freshwater crab family Trichodactylidae, IV. The genera Dilocarcinus and Poppiana (Crustacea: Decapoda: Brachyura). Senckenbergiana biologica, 88: 185-215.

Mora-Day, J. and Blanco-Belmonte, L. 2008. Macroinvertebrados acuáticos del alto río Paragua, Cuenca del río Caroní, Estado Bolívar, Venezuela. p. 97-109. In: Señaris, J.C.; C.A. Lasso and A.L. Flores (eds), Evaluación rápida de la biodiversidad de los ecosistemas acuáticos de la cuenca alta del Río Paragua, Estado Bolívar, Venezuela. Arlington, VA, Conservation International. (RAP Bulletin of Biological Assessment, 49)

Mora-Day, J.; Magalhães, C.; El Souki, M. and Blanco-Belmonte, L. 2008. Macroinvertebrados acuáticos de los ríos Cuyuní y Uey, cuenca del Cuyuní, Estado Bolívar, Venezuela. p. 89-105. In: C.A. Lasso; J.C. Señaris; A. Rial and A.L. Flores (eds), Evaluación rápida de la biodiversidad de los ecosistemas acuáticos de la cuenca alta del Río Cuyuní, Guayana Venezolana. Arlington, VA, Conservation International. (RAP Bulletin of Biological Assessment, 55)

Moreira, C. 1901. Contribuições para o conhecimento da fauna brazileira. Crustaceos do Brazil. Archivos do Museu Nacional do Rio de Janeiro, 11: 1-152, pls. 1-5.

Pereira, G. and García, J.V. 2006. Comunidad de crustáceos de la confluencia de los ríos Orinoco y Ventuari, Estado Amazonas, Venezuela. p. 107-113. In: C.A.Lasso; J.C. Señarìs;
L.E. Alonso and A. Flores (eds), Evaluación rápida de la biodiversidad de los ecosistemas acuáticos en la confluencia de los ríos Orinoco y Ventuari, Estado Amazonas (Venezuela). Washington, D.C., Conservation International. (RAP Bulletin of Biological Assessment, 30)

Randall, J.W. 1840. Catalogue of the Crustacea brought by Thomas Nuttall and J. K. Townsend, from the west coast of North America and the Sandwich Islands, with descriptions of such species as are apparently new, among which are included several species of different localities, previously existing in the collection of the Academy. Journal of the Academy of Natural Sciences of Philadelphia, 8: 106-147, pls. 3-7.

Rodriguez, G. 1966. Three new species of Pseudothelphusa from Venezuela (Crustacea Brachyura Potamonidae). Zoologische Mededelingen, 41: 259-267.

Rodriguez, G. 1982. Les crabes d'eau douce d'Amerique. Famille des Pseudothelphusidae. Paris, Editions ORSTOM, 224p. (Collection Faune Tropicale, 22)

Rodriguez. G. 1992. The Freshwater Crabs of America. Family Trichodactylidae and Supplement to the Family Pseudothelphusidae. Paris, Editions ORSTOM. 189p. (Collection Faune Tropicale, 31)

Rodríguez, G. and Campos, M.R. 1998. A cladistic revision of the genus Fredius (Crustacea: Decapoda: Pseudothelphusidae) and its significance to the biogeography of the Guianan lowlands of South America. Journal of Natural History, 32: 763-775.

Rodriguez, G. and Pereira, G. 1992. New species, cladistic relationships, and biogeography of the genus Fredius (Decapoda: Brachyura: Pseudothelphusidae) from South America. Journal of Crustacean Biology, 12: 298-311.

Rodríguez, G. and Suárez, H. 1994. Fredius stenolobus, a new species of freshwater crab (Decapoda: Brachyura: Pseudothelphusidae) from the Venezuelan Guiana. Proceedings Biological Society Washington, 107: 132-136.

Santos, U.M.; Bringel, S.R.B.; Ribeiro, M.N.G. and Silva, M.N.P. 1985. Rios da bacia amazônica II. Os afluentes do rio Branco. Acta Amazonica, 15: 147-156.

Vieira, I.M. 2008. Inventários rápidos da fauna de crustáceos do Parque Nacional Montanhas do Tumucumaque: Expedições I a V. p. 66-71. In: E. Bernard (ed), Inventários biológicos rápidos no Parque Nacional Montanhas do Tumucumaque, Amapá, Brasil. Arlington, VA, Conservation International. (RAP Bulletin of Biological Assessment, 48)

White, A. 1847. Short description of some new species of Crustacea in the collection of the British Museum. Proceedings of the Zoological Society of London, 1847: 84-86. 